\title{
gp130 cytokines are positive signals triggering changes in gene expression and axon outgrowth in peripheral neurons following injury
}

\author{
Richard E. Zigmond* \\ Department of Neurosciences, Case Western Reserve University, Cleveland, OH, USA
}

Edited by:

Simone Di Giovanni, HIH, University

of Tuebingen, Germany

\section{Reviewed by:}

Simone Di Giovanni, HIH, University of Tuebingen, Germany

Hwan Tae Park, Dong-A University

Medical School, South Korea

\section{*Correspondence:}

Richard E. Zigmond, Department of Neurosciences, Case Western

Reserve University, 10900 Euclid

Avenue, Cleveland, $\mathrm{OH} 44106-4975$,

USA.

e-mail: rez@case.edu
Adult peripheral neurons, in contrast to adult central neurons, are capable of regeneration after axonal damage. Much attention has focused on the changes that accompany this regeneration in two places, the distal nerve segment (where phagocytosis of axonal debris, changes in the surface properties of Schwann cells, and induction of growth factors and cytokines occur) and the neuronal cell body (where dramatic changes in cell morphology and gene expression occur). The changes in the axotomized cell body are often referred to as the "cell body response." The focus of the current review is a family of cytokines, the glycoprotein 130 (gp130) cytokines, which produce their actions through a common gp130 signaling receptor and which function as injury signals for axotomized peripheral neurons, triggering changes in gene expression and in neurite outgrowth. These cytokines play important roles in the responses of sympathetic, sensory, and motor neurons to injury. The best studied of these cytokines in this context are leukemia inhibitory factor (LIF) and interleukin (IL)-6, but experiments with conditional gp130 knockout animals suggest that other members of this family, not yet determined, are also involved. The primary gp130 signaling pathway shown to be involved is the activation of Janus kinase (JAK) and the transcription factors Signal Transducers and Activators of Transcription (STAT), though other downstream pathways such as mitogen-activated protein kinase (MAPK)/extracellular signal-regulated kinase (ERK) may also play a role. gp130 signaling may involve paracrine, retrograde, and autocrine actions of these cytokines. Recent studies suggest that manipulation of this cytokine system can also stimulate regeneration by injured central neurons.

Keywords: axotomy, conditioning lesion, galanin, gp130 cytokine, neuropeptide, regeneration associated genes, sympathetic ganglion, vasoactive intestinal peptide

\section{RESPONSES OF THE DISTAL NERVE AND THE AXOTOMIZED CELL BODY AFTER PERIPHERAL NERVE TRANSECTION}

Following injury to an adult peripheral nerve trunk resulting from transection, crushing, or freezing, the axonal segments distal to the site of injury degenerate. This process occurs over a period of a few days, involves axonal degeneration and phagocytosis by infiltrating macrophages and Schwann cells, and is referred to as Wallerian degeneration (Vargas and Barres, 2007; Gaudet et al., 2011). While this was previously thought to be a totally passive process as a consequence of the severed axons being cut off from the vast array of proteins normally supplied from their cell bodies via axonal transport, studies over the last 25 years have shown that not to be the case. In the slow Wallerian degeneration mouse (Wlds), axonal degeneration after a lesion can take several weeks (Deckwerth and Johnson, 1994; Coleman and Freeman, 2010).

At the same time that clearance of axonal debris occurs in the distal nerve stump, a suitable pathway is created through which regenerating axons eventually reach appropriate targets (Fu and Gordon, 1997; Barrette et al., 2010). In addition, the non-neuronal cells that make up this structure, particularly the
Schwann cells and macrophages, begin to synthesize a variety of trophic factors and cytokines (Gordon, 2009; Barrette et al., 2010). These molecules are clearly neuroactive and many promote neurite outgrowth when given exogenously, and, therefore, it is often assumed that they promote regeneration in vivo, though there has been little direct evidence for this hypothesis. For example, following transection of the sciatic nerve it has been shown that the neurotrophin receptor $\mathrm{p} 75$ and the neurotrophin nerve growth factor (NGF) are up-regulated by non-neuronal cells, and it was originally proposed that NGF binding to these receptors played an important role in sensory and sympathetic nerve regeneration (Taniuchi et al., 1986; Heumann et al., 1987; Taniuchi et al., 1988). However, evidence from Diamond and colleagues and others demonstrated that sensory and sympathetic regeneration is not affected by blockade of endogenous NGF, although under the same conditions collateral sprouting is blocked (Rich et al., 1984; Diamond et al., 1987, 1992; Gloster and Diamond, 1992, 1995; Doubleday and Robinson, 1995).

Nevertheless, Wallerian degeneration is important for regeneration to occur, as slow degeneration has been shown to retard peripheral nerve regeneration in sensory and motor axons 
(Bisby and Chen, 1990; Brown et al., 1992; Chen and Bisby, 1993a,b). This effect could be the result of a physical barrier presented by the distal axons, the slow removal of inhibitory molecules released as a result of the injury, or the delay in secretion of a variety of factors from denervated Schwann cells, and it is likely to result from all three (Brown et al., 1991, 1992; Perry and Brown, 1992).

A great deal is known about the cell biology and biochemistry of Wallerian degeneration; however, little is known about the signaling molecules that trigger this process. Recent studies indicate a role for damage-associated molecular patterns (DAMPs), which stimulate Toll-like receptors and initiate the release of subsequent signaling molecules like monocyte chemoattractant peptide-1, which plays an important role in triggering the influx of macrophages (Karanth et al., 2006; Lee et al., 2006; Boivin et al., 2007).

In contrast to these axonal changes that occur distal to the site of nerve injury, minimal changes occur in the injured nerve proximal to the injury except in the region immediately next to the site of injury (e.g., Heumann et al., 1987; Curtis et al., 1994); however, dramatic changes occur in the region of the axotomized neuronal cell bodies. Early evidence of this came from histological studies in 1892 by Franz Nissl, who described within $24 \mathrm{~h}$ of a peripheral nerve transection dissolution of "Nissl bodies" (later identified as rough endoplasmic reticulum) in neurons in the anterior horn, swelling of the nucleus and cytoplasm, and a change in the shape and position of the nucleus (quoted in Leinfelder, 1938). This phenomenon was termed chromatolysis. On a biochemical level, the axotomized neuronal cell bodies increase their overall synthesis of both mRNA and protein (Watson, 1974). When individual mRNAs and proteins are examined, not surprisingly, one finds both increases and decreases. For example, axotomized dorsal root ganglia (DRG), superior cervical sympathetic ganglia (SCG), and facial motor neurons have been examined by gene microarray analysis, and substantial changes in individual mRNAs have been documented (Costigan et al., 2002; Boeshore et al., 2004; Zujovic et al., 2005). At the protein level, increases and decreases have also been documented. For example, in sensory and motor neurons increases in tubulin and decreases in neurofilament levels have been found (Quesada et al., 1986; Greenberg and Lasek, 1988; Oblinger and Lasek, 1988; Tetzlaff et al., 1988) and similar changes have been found in the SCG at the mRNA level (Boeshore et al., 2004). Together these morphological and biochemical changes have been referred to by various investigators as the cell body response (Grafstein, 1975; Hendry, 1992), the cell body reaction (Titmus and Faber, 1990), or the axon reaction (Lieberman, 1971; Hanz and Fainzilber, 2006). The genes whose expression increases after axotomy are referred to as regeneration associated genes (RAGs) (Fernandes et al., 1999). It has often been pointed out that these histological and molecular biological changes in the axotomized cell body occur at a time that the neuron shifts its activity from synaptic transmission to regeneration, and it is hypothesized that the changes underlie this functional switch (Matthews and Raisman, 1969; Cheah and Geffen, 1973; Grafstein, 1975; Grafstein and McQuarrie, 1978; Hyatt-Sachs et al., 1993).

\section{CHANGES IN NEUROPEPTIDE EXPRESSION IN PERIPHERAL NEURONS AFTER AXOTOMY IN VIVO AND IN CULTURE}

One conspicuous change in the cell bodies of adult peripheral neurons after axotomy is the expression of certain neuropeptides not previously expressed by these neurons (at least during adulthood) and the decreased expression of other peptides that are normally present (for reviews see Hokfelt et al., 1994; Zigmond et al., 1996; Zigmond, 1997). For example, following transection of the two major postganglionic trunks of the SCG, the internal and external carotid nerves, ganglionic neurons begin to express vasoactive intestinal peptide (VIP), galanin, pituitary adenylate cyclase activating polypeptide (PACAP), substance P, and cholecystokinin (CCK) and down regulate their expression of neuropeptide Y (NPY) (Hyatt-Sachs et al., 1993; Rao et al., 1993b; Klimaschewski et al., 1994; Mohney et al., 1994; Schreiber et al., 1994; Zhang et al., 1994; Klimaschewski et al., 1996; Sun and Zigmond, 1996a; Moller et al., 1997a; Habecker et al., 2009). Interestingly, VIP, galanin, and PACAP are also up-regulated after axotomy of DRG neurons and motor neurons, and therefore, should be considered RAGs (Shehab and Atkinson, 1986; Hokfelt et al., 1987; Moore, 1989; Saika et al., 1991; Zhang et al., 1995; Zhou et al., 1999; Zigmond, 2001). In the case of CCK, increases were also reported in the DRG and facial motor nucleus (Saika et al., 1991; Verge et al., 1993), although a decrease has been reported in axotomized lumbar motor neurons (Piehl et al., 1993).

The functional significance of these increases in peptide expression has not been determined in every case but considerable evidence exists that at least some of these changes facilitate regeneration. Perhaps the best case is for the increase in galanin in DRGs. Functional regeneration determined by the toe spreading index was delayed in galanin -/- mice for three weeks after sciatic nerve crush (Holmes et al., 2000). A somewhat less striking deficit in regeneration of facial motor neurons and an exaggerated neuroinflammatory response were observed in PACAP -/- mice after facial nerve crush (Armstrong et al., 2008). Both PACAP and VIP, though not galanin, have been shown to stimulate neurite outgrowth in PC12 cells (Deutsch et al., 1993; Okumura et al., 1994; Klimaschewski et al., 1995). PACAP also stimulates neurite outgrowth in embryonic DRG and SCG cultures (Lioudyno et al., 1998; DiCicco-Bloom et al., 2000). On the other hand, galanin does stimulate neurite outgrowth in cultured adult DRG neurons (Mahoney et al., 2003; Suarez et al., 2006). In addition, evidence exists that VIP in the SCG and galanin in the DRG may promote neuronal survival after injury (Klimaschewski et al., 1995; Holmberg et al., 2005).

Changes in neuropeptide expression similar to those seen after axotomy occur in SCG in explant cultures. The first reported example of this was an increase in substance $\mathrm{P}$ protein (Adler and Black, 1984). Subsequent studies demonstrated increases in protein levels for VIP, galanin, and PACAP in such preparations (Zigmond et al., 1992; Schreiber et al., 1994; Moller et al., 1997b).

The simplest explanation for an increase in a neuropeptide level in a neuronal cell body after axotomy (or after being placed in explant culture) is that it is due to the buildup of neuropeptide that would normally be transported down the axon, and, in fact, in early experiments, axonal transport blockers 
such as colchicines were used in immunohistochemical studies to increase detection of normally expressed neuropeptides with that reasoning in mind (e.g., Moore, 1989). However, in all the cases cited above, it has been found that the increases in neuropeptides are accompanied by increases in the respective mRNAs (for reviews see Hokfelt et al., 1994; Zigmond et al., 1996), suggesting they result from increased gene expression and not just interference with transport away from the cell body.

In sympathetic neurons and motor neurons, axotomy leads to "synaptic stripping" of the afferent inputs to the neurons and decreased synaptic transmission (Brown and Pascoe, 1954; Blinzinger and Kreutzberg, 1968; Matthews and Nelson, 1975), and, of course, axotomy of the peripheral axonal branch of a sensory neuron leads to decreased on-going sensory nerve activity. In early studies, it was proposed that decreased sympathetic nerve activity leads to the increased expression of substance $\mathrm{P}$ in cultured SCG (Black et al., 1982); however, this interpretation of these findings has since been questioned (Sun et al., 1992). In fact, the finding for a variety of neuropeptides that increase their expression after axotomy in the SCG (i.e., galanin, PACAP, substance P, VIP) is that their expression also goes up after depolarization in culture (Sun et al., 1992; Brandenburg et al., 1997; Klimaschewski, 1997). Furthermore, the increases in neuropeptide expression seen after cutting the predominantly preganglionic cervical sympathetic trunk (CST) (i.e., deafferentation or decentralization of the ganglion), thus silencing neurons in the SCG, are small compared to those seen after axotomy (Kessler and Black, 1982; Hyatt-Sachs et al., 1993; Rao et al., 1993b; Schreiber et al., 1994; Moller et al., 1997a). The few new peptidergic neurons seen after surgical deafferentation are likely to be due to a small population of neurons in the SCG that project their axons into the CST and are thus axotomized and deafferented by the surgery (Bowers and Zigmond, 1979; Mohney et al., 1994; Zigmond and Vaccariello, 2007).

Is the induction of these neuropeptides simply caused by some non-specific trauma produced by the surgery, which, in the case of the SCG, occurs quite close to the neuronal cell bodies (Zigmond, 1997)? The minor effect caused by deafferentation, also performed close to the ganglion, suggests this is not the case (Zigmond, 1997). Furthermore, injury to the axons of neurons in the inferior and middle cervical ganglion made at some distance from their cell bodies produces similar changes in neuropeptide expression (Shadiack et al., 1995). Finally, if sympathetic nerve terminals are lesioned chemically, again at some distance from their neuronal cell bodies, by administration of the adrenergic neurotoxin 6-hydroxydopamine, changes in galanin and VIP mRNA occur that are comparable to those seen after close surgical axotomy (Hyatt-Sachs et al., 1996). Distal chemical axotomy of sensory neurons with capsaicin (Chung et al., 1990) or resiniferatoxin, a potent capsaicin analog, lead to an increase in VIP and galanin mRNA in DRG neurons (Farkas-Szallasi et al., 1995; Kashiba et al., 1997).

While sympathetic, sensory, and motor neurons respond similarly to axotomy with respect to some neuropeptides (i.e., VIP, galanin, and PACAP), they differ in terms of others. For example, after axotomy, substance $\mathrm{P}$ is up-regulated in neurons in the SCG, as noted above, but it is down-regulated in the DRG
(Nielsch and Keen, 1989; Noguchi et al., 1989; Rao et al., 1993b). In addition, NPY, which is down-regulated in the SCG, is upregulated in the DRG (Wakisaka et al., 1991). These results may reflect differences in the mixture of injury signals released in different neuronal systems.

\section{LEUKEMIA INHIBITORY FACTOR (LIF) ACTS AS A POSITIVE INJURY SIGNAL TRIGGERING CERTAIN OF THE CHANGES IN AXOTOMIZED NEURONS AFTER PERIPHERAL NERVE INJURY}

The signals that trigger retrograde changes in the cell bodies after axotomy have long been sought. In 1970, Cragg wrote a review paper entitled "What is the signal for chromatolysis" in which he addressed this question. Interestingly, this paper presented no new data. Rather in it Cragg enumerated 10 possible signals including changes in neural activity (such as immediate increases due to the injury itself or subsequent decreases due to synaptic stripping) and changes in the axonal transport of materials, either orthogradely or retrogradely. This field lay fallow for a number of years; however, eventually investigators began thinking in terms of positive and negative signals (Ambron and Walters, 1996). Positive signals were conceived of as molecules, which were not present, at least in their active form, in intact neurons but were produced in response to axotomy and stimulated aspects of the cell body response. Negative signals were the opposite, that is, they were present in intact neurons, normally suppressing the cell body response, but triggering this response when their influence was removed following axotomy.

Using induction of specific neuropeptides in the SCG after axotomy, we identified both a positive and a negative signal (Zigmond, 1997). The negative signal is nerve growth factor, which is normally taken up by sympathetic and sensory nerve endings from their peripheral target tissues and retrogradely transported back to the cell body (Oppenheim, 1996). Blockade of this on-going signal in unoperated animals with an antiserum to NGF produces a number of the changes in gene expression normally seen after axotomy (Zigmond, 1997; Shadiack et al., 1998, 2001). This system will not be discussed further in this article except in the case of NGF's modulation of the effects of glycoprotein 130 (gp130) cytokines.

Evidence for a positive signal first came from dissociated cell culture experiments. Following dissociation of neonatal SCG and plating of both the neurons and non-neuronal cells, VIP-like immunoreactivity (IR) increases 10-20-fold (Sun et al., 1992, 1994). When the dissociated cells were pre-plated to remove the non-neuronal cells, the increase in VIP-IR was greatly diminished. If, on the other hand, culture medium was preconditioned by ganglion non-neuronal cells and then placed on neuron-enriched cultures, it caused a 4 -fold induction of peptide levels compared to cultures treated with control medium (Sun et al., 1994).

In examining the chemical nature of the active component of the conditioned medium, we were influenced by earlier studies showing that exogenous application of two cytokines of the gp130 family, namely leukemia inhibitory factor (LIF) and ciliary neurotrophic factor (CNTF), which had originally been shown to trigger a switch in neonatal sympathetic neurons in culture from an adrenergic to a cholinergic phenotype (Saadat et al., 1989; 
Yamamori et al., 1989), also induced VIP expression (Ernsberger et al., 1989; Nawa et al., 1991). For this reason, we examined the effects of immunoprecipitating the non-neuronal cell conditioned medium with antibodies to LIF and CNTF (Sun et al., 1994). The anti-LIF antiserum completely blocked the stimulatory effect of the conditioned medium on VIP expression. On the other hand, anti-CNTF had no such effect. The anti-LIF neutralizing antiserum also reduced the increase in VIP-IR in explanted adult ganglia compared to the effect of normal serum, and this effect of the antiserum could be overcome by addition of human recombinant LIF, which is not recognized by the antiserum (Sun et al., 1994).

Only a very faint band with the mobility of LIF was found on gels after PCR of extracts from control ganglia. However, a strong signal for LIF was seen in extracts of ganglionic nonneuronal cells cultured for $48 \mathrm{~h}$, in SCG explants after $48 \mathrm{~h}$, and in extracts of SCG dissected $48 \mathrm{~h}$ after axotomy (Sun et al., 1994). Later studies using real-time PCR established that LIF mRNA was detectable in the axotomized SCG by $6 \mathrm{~h}$ and those levels were maintained for at least $48 \mathrm{~h}$ (Habecker et al., 2009). By in situ hybridization and Northern blot analysis, it was shown that the increase in LIF mRNA in vivo, as indicated by our cell culture experiments, occurs in non-neuronal cells, and it was suggested that these were satellite/Schwann cells (Banner and Patterson, 1994; Nagamoto-Combs et al., 1999). Studies in a rat Schwann cell line revealed that LIF mRNA levels were increased following treatment of the cells with either phorbol myristate acetate (PMA), a cAMP analog, or a calcium ionophore. The effect of PMA was substantially reduced by blockade of mitogen-activated protein kinase kinase (MEK), a kinase upstream of mitogenactivated protein kinase (MAPK)/extracellular signal-regulated kinase (ERK) (Nagamoto-Combs et al., 1999). Interestingly, it has been shown that transforming growth factor-beta (TGF- $\beta$ ) stimulates LIF mRNA levels in Schwann cells, and this effect is mediated through protein kinase C (Matsuoka et al., 1997). Which of these second messenger pathways are involved in LIF induction after axotomy is not known?

While immunohistochemistry revealed CNTF-IR in myelinated Schwann cells in the sciatic nerve, no staining was seen in non-myelinating Schwann cells in the SCG (Dobrea et al., 1992). To determine whether CNTF was present in the extracts of non-neuronal cell conditioned medium, a CNTF bioassay was used (i.e., survival of and process outgrowth from chick ciliary neurons). No evidence for CNTF bioactivity in the medium conditioned by SCG non-neuronal cells was found. Later studies revealed that, while low levels of CNTF mRNA are detectable in the SCG by real-time PCR, the levels do not change after axotomy (Habecker et al., 2009).

To test the role of LIF in neuropeptide induction after injury in vivo, experiments were performed with LIF null mutant mice (Escary et al., 1993). When the two major postganglionic trunks of the SCG were transected in adult mice and peptide IR was assayed, the increases in expression of VIP, galanin, and neurokinin A (a peptide that together with substance $\mathrm{P}$ is produced from the $\beta$-preprotachykin precursor protein) were significantly reduced in the LIF -/- mice compared to wild type animals (Rao et al., 1993a). In addition, these knockout mice exhibited a partial reduction in the increase in VIP and galanin mRNA following axotomy (Sun and Zigmond, 1996a). These findings constitute the first evidence for an effect of endogenous LIF on the nervous system in vivo. Interestingly, in these LIF -/- mice, small but significant increases in the peptides and their mRNAs were still seen (Rao et al., 1993a). A likely explanation of these partial effects of the gene deletion is that additional biological activities are involved. It is striking that in these mutant animals the developmental switch of certain sympathetic neurons from an adrenergic to a cholinergic phenotype was unaffected, indicating that, contrary to expectations, LIF does not play a necessary role in that process (Rao et al., 1993a).

\section{INVOLVEMENT OF OTHER gp130 CYTOKINE FAMILY MEMBERS}

LIF and CNTF belong to a family of cytokines, which is referred to as either the interleukin (IL)-6 family or the gp130 family. This family is quite large and includes, among other cytokines, IL-6, IL-11, oncostatin M, and cardiotrophin-1 along with LIF and CNTF (Taga and Kishimoto, 1997), with new members of the family still being identified (e.g., IL-31; for review see Cornelissen et al., 2011). These cytokines are pleiotropic and have overlapping functional effects. Members of the IL- 6 family are identified by virtue of their three-dimensional structure, rather than by significant homology in their amino acid sequence, and form four anti-parallel helix bundles (Bazan, 1991). The name gp130 family, which we will adopt, is based on the fact that members of the family act on heteromeric receptors, the intracellular signaling component of which is the protein gp130 (Taga and Kishimoto, 1997).

When mRNA for the six cytokines mentioned above was measured after axotomy in the SCG in vivo, IL-6, IL-11, and oncostatin $\mathrm{M}$ were found to increase rapidly together with LIF (Habecker et al., 2009). In order to block the action of all of the members of this peptide family, we used mice in which gp130 had been conditionally knocked out in neurons expressing dopamine$\beta$-hydroxylase (DBH), i.e., in sympathetic neurons, central noradrenergic and adrenergic neurons, and adrenal chromaffin cells (Stanke et al., 2006; for a review on the use of gp130 conditional knockouts see Fasnacht and Muller, 2008). Axotomy of the SCG in these knockout animals blocked the axotomy-induced increase in mRNAs for VIP, PACAP, and galanin completely. Strikingly, the increase in CCK mRNA was unaffected by the receptor deletion (Figure 1) (Habecker et al., 2009). This result is somewhat surprising given that, in an early study, LIF was shown to increase CCK in cultured neonatal SCG neurons (Fann and Patterson, 1993). At present, the signal leading to the axotomy-induced increase in CCK mRNA in vivo remains to be determined.

While detailed studies on the role of gp130 cytokines on peripheral neurons after axotomy has been restricted to sympathetic neurons, experiments in LIF -/- animals have also been carried out in the DRG after sciatic nerve transection, and the increase in galanin-IR and galanin mRNA were found to be partially blocked (Corness et al., 1996; Sun and Zigmond, 1996b). In these same studies, no significant decrease occurred in the induction of NPY. In contrast to the partial dependence of the axotomy-induced increase in galanin mRNA in the DRG on LIF, 

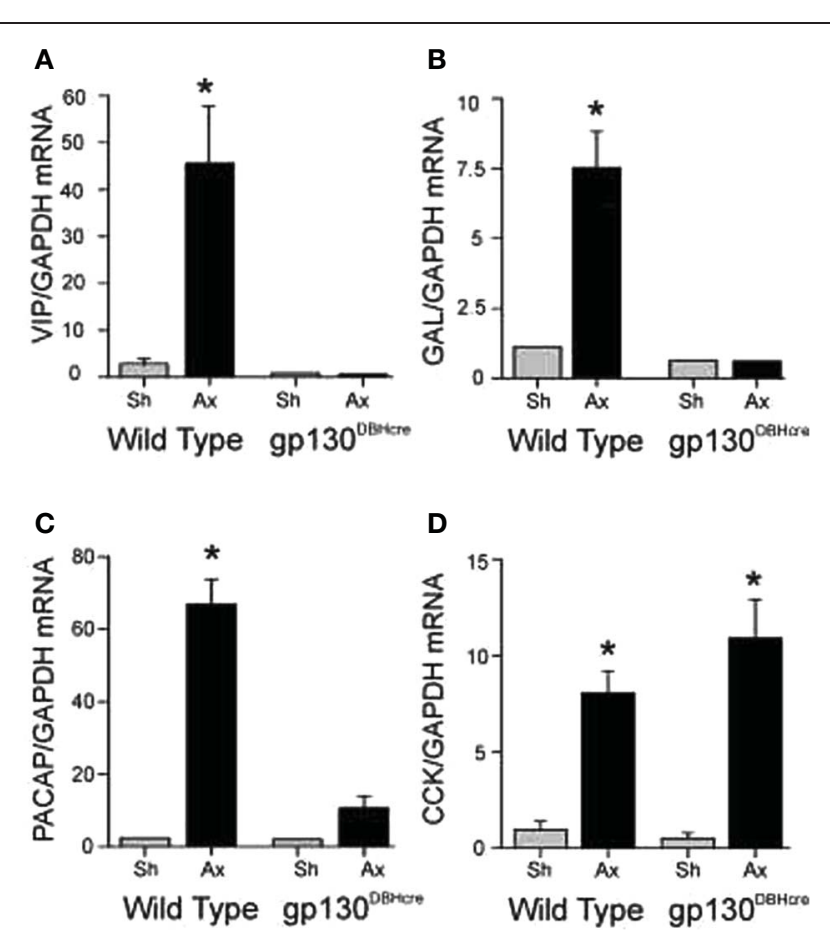

FIGURE 1 | Regulation of mRNA expression for several neuropeptides in the SCG after unilateral axotomy. Wild type and gp130 $0^{\mathrm{BH}} \mathrm{Hcre}$ mice were subjected to unilateral axotomy of the SCG, and mRNA levels for several neuropeptides and proteins were measured $48 \mathrm{~h}$ later in the ipsilateral $(A x)$ and contralateral (Sh) ganglia. The data are expressed relative to GAPDH mRNA in the same samples and represent the means \pm S.E.M. of 4-5 ganglia for VIP (A), galanin (B), and PACAP (C). These three mRNAs increased in the ipsilateral ganglia of the wild type mice 16-, 7-, and 28-fold, respectively, but did not increase in ganglia from knockout animals. However, cholecystokinin (CCK) mRNA was increased similarly in axotomized ganglia of mice of both genotypes (D). *Indicates $p<0.05$ compared to sham-operated ganglia of the same genotype compared by Student's $t$-test. The figure is from Habecker et al. (2009).

a normal response was found in IL-6 -/- mice (Murphy et al., 1999). LIF administration into the sciatic nerve increased the number of neurons in the DRG expressing galanin but did not affect the expression of VIP or NPY (Thompson et al., 1998).

In axotomized facial motor neurons, increases in PACAP and VIP mRNA did not differ between wild type mice and mice null for either LIF or IL-6 (Armstrong et al., 2003). Nevertheless, facial motor neurons express gp130 (Haas et al., 1999), and gp130 cytokines are known to affect the survival of these neurons after axotomy (Sendtner et al., 1996). It would certainly be of interest to examine PACAP and VIP expression in facial motor neurons after axotomy in mice with a conditional knockout of gp130 restricted to motor neurons.

Additional cytokines in this family, or at least related to it, continue to be identified. An example is IL-31 (Cornelissen et al., 2011). While neither the presence of nor the action on peripheral neurons have been described for this cytokine, IL-31 receptors have been identified in the rodent and human dorsal root ganglion (Bando et al., 2006; Sonkoly et al., 2006). Current data suggest that the IL-31 heterodimeric receptor is made up of the oncostatin $\mathrm{M}$ receptor and the IL-31 receptor $\alpha$ and does not involve gp130, thus making it quite unusual (Cornelissen et al., 2011). Nevertheless, one hypothesis is that the IL-31 receptor $\alpha$ arose by gene duplication of gp130 and that it retains many of the functions of the latter such as binding to Janus kinases (JAKs) and Signal Transducers and Activators of Transcription (STAT), a signal pathway discussed in more detail below (Cornelissen et al., 2011). The reason for mentioning this here is to raise the possibility that we may well have not accounted for all of the cytokines that are involved in the response of the peripheral nervous system to injury.

\section{INTERACTION OF POSITIVE AND NEGATIVE SIGNALS IN TRIGGERING CHANGES IN PERIPHERAL NEURONS}

Having established a role for LIF in the axotomy-induced increase in galanin mRNA, we examined the effect of placing a pellet of LIF next to the SCG in an intact animal. We were surprised that galanin was not induced under these conditions (Sun et al., 1993). We also observed that there was an increase in LIF expression in the SCG after deafferentation but little change in galanin expression (Shadiack et al., 1998). It appeared that LIF only induced galanin after axotomy. One signal that would correlate with the SCG neurons being in fact axotomized and no longer connected to their targets is a decrease in NGF in the ganglion (Korsching and Thoenen, 1985; Nagata et al., 1987; Zhou et al., 1994). We, therefore, examined the effect of the LIF pellet in intact animals in which we had injected antiserum to NGF to lower the level of this trophic factor in the ganglion (Shadiack et al., 1998). While injection of the antiserum alone in animals with a placebo pellet stimulated galanin expression somewhat, the combination of anti-NGF and the LIF pellet produced a dramatic synergistic effect (Figure 2). In addition, other animals in which LIF was increased in the SCG by deafferentation were also injected with anti-NGF. In those animals there was a small increase in galanin mRNA in response to either deafferentation or anti-NGF, but there was a synergistic effect if the two treatments were given together (Shadiack et al., 1998).

Experiments with explanted SCG also suggested an antagonistic relationship between LIF and NGF on galanin expression. As already noted the high levels of galanin-IR seen after $48 \mathrm{~h}$ in explant culture can be inhibited by a neutralizing antiserum to LIF (Sun et al., 1994). In addition, these levels can be substantially reduced by addition of NGF, an effect that can be blocked by an antiserum to NGF (Figure 3; Shadiack et al., 2001). Similar experiments were carried out in embryonic DRG neurons. In that case, NGF completely blocked the effect of LIF to elevate galanin mRNA (Corness et al., 1998). In vivo, the increase in galanin mRNA that occurs in the DRG after sciatic nerve transection, can be partially reversed by intrathecal administration of NGF (Verge et al., 1995). While the mechanism behind these interactions between NGF and gp130 cytokines is not fully understood, NGF has been shown to inhibit the axotomy-induced activation of the transcription factor STAT3 (Rajan et al., 1998), which as discussed below seems to mediate many of the effects of gp130 cytokines after axotomy. It should be noted, however, that in PC12 cells, NGF actually stimulates STAT3 phosphorylation (albeit at a different amino acid residue than gp130 cytokines) 


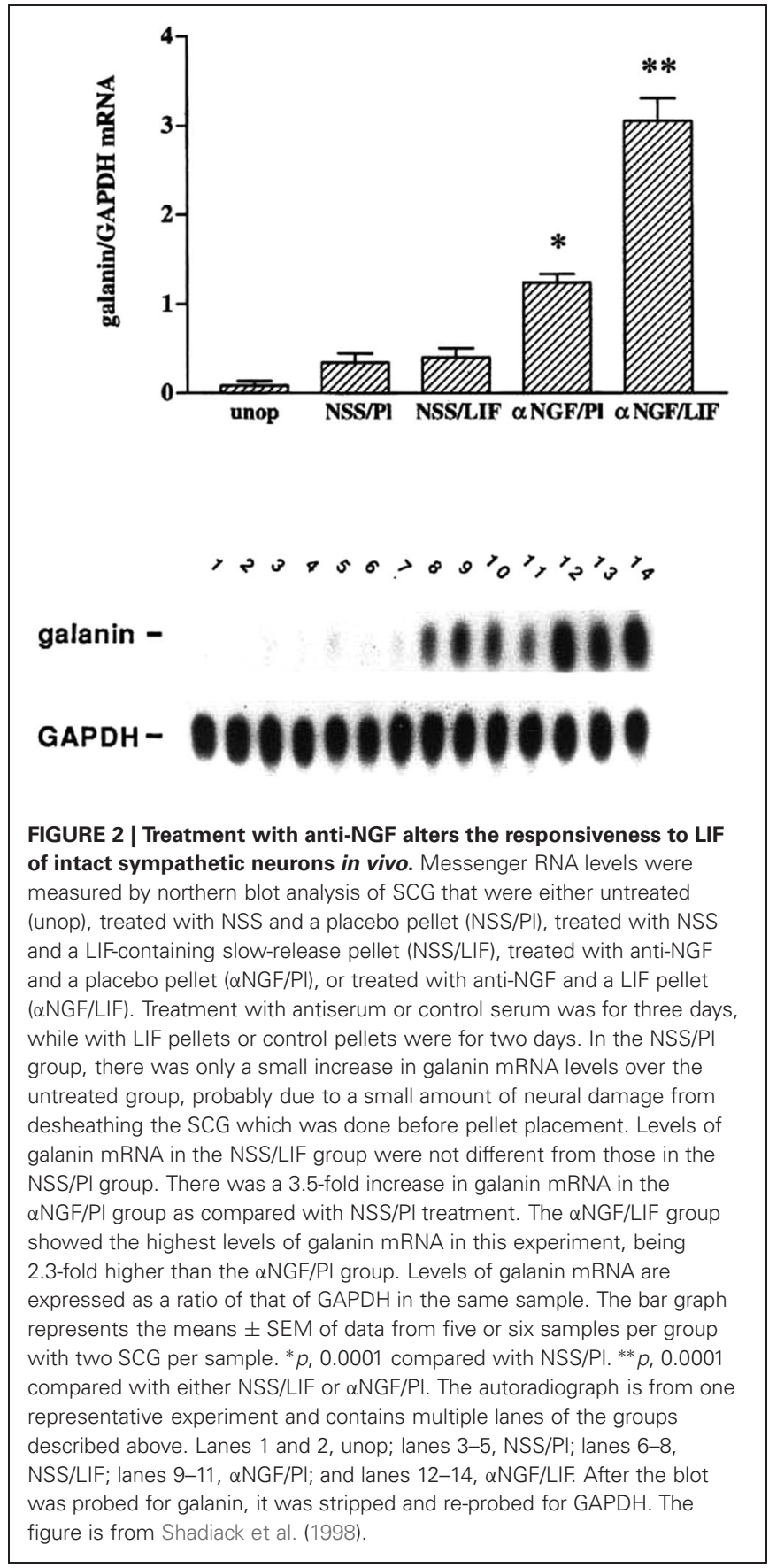

and the binding of the transcription factor to DNA (Ng et al,, 2006). The reason for this apparent discrepancy remains to be determined.

\section{CYTOKINE DEPENDENCE OF OTHER REGENERATION ASSOCIATED GENES OR DOWNSTREAM EFFECTORS}

Neuropeptides are not the only genes that are up-regulated after axotomy via gp130 cytokines. The best studied cytokinedependent RAG after VIP is a membrane-bound metallopeptidase, damage-induced neuronal endopeptidase (DINE), which is increased after axotomy in a variety of motor nuclei, in DRGs,

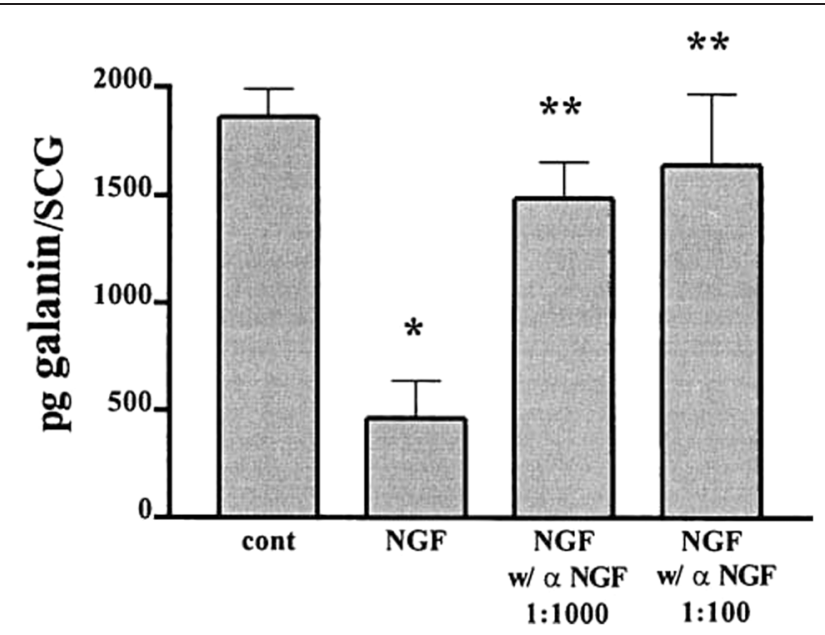

FIGURE 3 | NGF inhibits the increase in galanin-IR and this effect is completely reversed by an NGF antiserum. Adult SCG were cultured for $48 \mathrm{~h}$ in F12 medium alone or in the presence of $50 \mathrm{ng} / \mathrm{ml}$ NGF. To some of the NGF-treated cultures we also added different concentrations of an antiserum to NGF. Galanin-IR was assayed by radioimmunoassay in individual SCG. Data are the means of six ganglia \pm SEM; * $p, 0.004$ vs. control and ${ }^{* *} p, 0.02$ vs. NGF. The figure is from Shadiack et al. (2001).

and in SCGs (Kiryu-Seo et al., 2000; Boeshore et al., 2004). LIF, but not CNTF or IL-6, increased DINE mRNA in organ cultured neonatal DRG and injection of LIF into the sciatic nerve in vivo led to a similar increase in the axotomized DRGs (Kato et al., 2002). Furthermore, the increase in DINE mRNA in the DRG after sciatic nerve injury was partially blocked by injecting an anti-gp130 antibody into the injured nerve (Kato et al., 2002). LIF also stimulated activity in a DINE promoter assay (Kiryu-Seo et al., 2008). Interestingly, the participation of STAT3 in regulating DINE expression does not seem to be due to its direct binding to a cytokine response element, rather it has been hypothesized that STAT3 plus two other transcription factors, which are up-regulated after axotomy, ATF3, and c-Jun, interact with the general transcription factor, Sp1, which in turn binds to a GC box within the DINE promoter.

In addition to DINE and the neuropeptides discussed above, mRNA for one of the rat substance $\mathrm{P}$ receptors is increased in the SCG after axotomy (Ludlam et al., 1995), and studies in vitro demonstrate that LIF and CNTF can increase this message in both dissociated and explanted sympathetic neurons (Ludlam et al., 1994). Pancreatitis-associated protein, referred to as REG2 , is up-regulated in sensory, motor, and sympathetic neurons after axotomy (Livesey et al., 1997; Boeshore et al., 2004), and its expression has been shown to be sensitive to gp130 cytokines acting through STAT3 (Livesey et al., 1997; Nishimune et al., 2000; Schweizer et al., 2002). The neuronal intermediate filament protein peripherin increases after axotomy in the DRG and in spinal motor neurons (Oblinger et al., 1989; Troy et al., 1990; Wong and Oblinger, 1990), contains a gp130 cytokine response element (Lecomte et al., 1998), and is induced by IL-6 in PC12 cells and by LIF in a neuroblastoma cell line (Sterneck et al., 1996; Lecomte et al., 1998). Finally, IL-6 has been shown to increase growth associated protein- 43 (GAP-43) in PC12 cells (Marz et al., 1997), 
and the increase in GAP-43 normally seen in DRGs after axotomy is abolished in IL-6 -/- mice (Cafferty et al., 2004). Whether the effects of gp130 cytokines on the expression of the proteins mentioned in this paragraph are "direct" (i.e., whether the respective genes have a gp130 cytokine response element) and whether the increases in mRNA expression after axotomy are dependent on gp130 cytokines has not been examined in every case.

In a recent paper, IL-6 was shown to mediate chloride accumulation in axotomized sensory neurons via the phosphorylation of the $\mathrm{Na}^{+}, \mathrm{K}^{+}, \mathrm{Cl}^{-}$cotransporter NKCC1 (Pieraut et al., 2011). This phenomenon is relevant because NKCC1 phosphorylation and intracellular chloride accumulation has been shown to stimulate neurite outgrowth in axotomized DRG neurons in culture (Pieraut et al., 2007). The effect of IL-6 is blocked by inhibitors of JAK; however, the kinase that phosphorylated NKCC1 has not been identified. In vivo, axotomy leads to increased NKCC1 phosphorylation without a change in the level of transcripts for this cotransporter. Increased phospho-NKCC1 was not seen after axotomy in IL-6 -/- mice (Pieraut et al., 2011).

\section{CYTOKINE RECEPTORS IN NORMAL AND AXOTOMIZED PERIPHERAL NEURONS}

By definition, all gp130 cytokines act through a receptor that contains one or perhaps two gp130 subunits. This subunit is present in intact neurons in the SCG (Wong et al., 1995), DRG (Gardiner et al., 2002), and cranial and spinal motor nuclei (Watanabe et al., 1996). gp130 mRNA does not change after axotomy in SCG (Banner and Patterson, 1994), DRG (Gardiner et al., 2002; Brazda et al., 2009) or facial motor neurons (Haas et al., 1999).

The exact subunit composition of the receptor with which gp130 cytokines interact varies for each cytokine. For example, LIF interacts with a heterodimer made up of a gp130 subunit and a LIF receptor, while IL- 6 interacts with a heterotrimer made up of two gp130 subunits and a specific IL-6 receptor (e.g., Heinrich et al., 1998). The regulation of the expression of the LIF receptor is different in different types of peripheral neurons. In the SCG, LIF receptor mRNA decreases after axotomy (Banner and Patterson, 1994), in the DRG, the level of the receptor remains constant though its subcellular localization is said to be altered from nucleus to cytoplasm (Gardiner et al., 2002), while in facial motor nucleus and ventral horn the LIF receptor increases (Haas et al., 1999; Hammarberg et al., 2000). In spite of this diversity, however, as noted previously, LIF affects each of these classes of neurons after axotomy.

With regard to the IL-6 receptor, the situation in the SCG and DRG is not completely clear. It has been reported by RT-PCR and in situ hybridization that IL-6 receptor mRNA is expressed in neurons in both adult SCG and DRG (Gadient and Otten, 1996; Marz et al., 1996; Shuto et al., 2001); however, in pharmacological studies with cultured neonatal SCG neurons, addition of IL-6 in the absence of the IL-6 soluble receptor apparently produced little effect on neuropeptide expression (Marz et al., 1998). In seeming contrast, intrathecal injection of IL- 6 by itself led to an increase in expression of galanin mRNA in the DRG (Murphy et al., 1999). Using either neurite outgrowth or neuronal survival as an assay, a dependence of IL-6's action on the addition of a soluble IL- 6 receptor in embryonic and newborn
DRG neurons respectively has been reported (Hirota et al., 1996; Thier et al., 1999). Nevertheless, in adult DRG explants or in isolated adult DRG neurons (in the presence of NGF), IL-6 did not require the addition of a soluble IL-6 receptor to stimulate neurite outgrowth (Shuto et al., 2001; Cafferty et al., 2004). Unfortunately, the level of IL-6 receptor protein in these studies was not assessed. In this context, it is interesting to note that in hypoglossal neurons IL-6 receptor protein measured by immunohistochemistry was increased dramatically one week after axotomy (Hirota et al., 1996). In the facial motor neurons after a unilateral facial nerve lesion, however, IL-6 receptor IR was clearly visible and no differences were noted on the ipsilateral and contralateral motor nucleus two days after the lesion (Klein et al., 1997).

The findings that in some situations exogenous IL-6 does not produce an effect unless exogenous soluble IL- 6 receptor is also added has led to the concept of trans-signaling (Marz et al., 1999; Jones et al., 2001; Rose-John, 2003; Jones et al., 2005). The idea is that certain targets of IL-6 express gp130 though not the IL-6 receptor, but that a soluble form of the IL6 receptor is expressed and released by nearby cells, and, after combining with IL-6, leads to activation of gp130. While at least two studies have described this phenomenon in the central nervous system (CNS) (Linker et al., 2008; Burton et al., 2011), we are not aware of any demonstration of such signaling involving neurons; however, perhaps the dorsal root ganglion is a system worth examining where one can imagine IL-6 receptors being released by satellite/Schwann cells and facilitating the autocrine stimulation of neurons (see further discussion below). In this regard, IL-6 receptors were shown to increase in DRG satellite cells after chronic sciatic nerve constriction (Dubovy et al., 2010), though not after nerve transection (Pieraut et al., 2011), and to increase in Schwann cells in the sciatic nerve after a nerve crush (Bolin et al., 1995). Another possibility would be the release of soluble IL-6 receptors by macrophages (Horiuchi et al., 1994), which are known to infiltrate into sensory and sympathetic ganglia following axotomy (Lu and Richardson, 1993; Schreiber et al., 1995), although at least in the SCG this occurs with some delay after the peak in IL-6 induction (Habecker et al., 2009). Finally, it should be noted that soluble receptors also exist for other gp130 cytokines (Jones and Rose-John, 2002) and could be involved in transsignaling.

\section{WHAT ARE THE MOLECULAR MECHANISMS BY WHICH CYTOKINES LEAD TO PEPTIDE INDUCTION AFTER AXOTOMY?}

gp130 cytokines can act on neurons by at least two signaling pathways (Taga and Kishimoto, 1997). One of these is the JAK/STAT pathway, in which occupation of a cytokine receptor leads to the activation of a JAK and the phosphorylation, activation, and nuclear translocation of a STAT transcription factor, leading to its binding to a cytokine response element on a gene promoter. gp130 receptor stimulation can also lead to activation of the Ras/MAPK pathway.

Almost all studies on cytokine action on peripheral neurons have focused on the first such pathway. Two exceptions involve the 
cytokine suppression of the adrenergic phenotype in a neuroblastoma cell line (Dziennis and Habecker, 2003; Shi and Habecker, 2012). In the first study, inhibition of ERK kinase was shown to block the decrease in $\mathrm{DBH}$ protein produced by CNTF, though somewhat surprisingly not the decrease in DBH mRNA. In the second study, CNTF increased the ubiquitination of tyrosine hydroxylase and decreased the protein half-life of the enzyme, and these effects were blocked by an ERK kinase inhibitor but not by a STAT3 inhibitor. A final example of an ERK-mediated gp130 cytokine action concerns IL-6-induced allodynia (Melemedjian et al., 2010). In this system, IL-6 leads to ERK phosphorylation which leads to the activation of MAP kinase-interacting kinase 1 (Mnk1) which causes the phosphorylation of the eukaryotic initiation factor (eIF) 4E leading to enhanced protein translation. Notably all three examples cited demonstrate cytokine effects on protein levels, which are not mediated through changes in gene transcription.

In contrast to these ERK-mediated effects of gp130 cytokines, the regulation of VIP expression by CNTF and LIF in a neuroblastoma cell line indicated that these inductions occur by a Ras-independent pathway (Johnson and Nathanson, 1994). LIF stimulates the binding of STAT3 to the cytokine response element in the VIP gene in cultured sympathetic neurons (Symes et al., 1994). In a neuroblastoma cell line, deletion of this DNA binding site for STAT attenuated the transcription of VIP by gp130 cytokines (Symes et al., 1994). Further studies indicated that additional transcription factors also act within the cytokine response element in the stimulation of VIP expression by LIF and CNTF (Symes et al., 1995); however, the role of such factors in the response to axotomy remains unclear.

The role of the JAK/STAT pathway in the regulation of PACAP and galanin does not seem to have been explored beyond the observation that an enhancer region in the galanin promoter that is necessary for axotomy-induced up-regulation in the DRG after sciatic nerve transection contains an 18 bp region with overlapping putative Stat-, Smad-, and Ets-binding sites and a 23 bp region with adjacent Stat and Smad-binding sites (Bacon et al., 2007). Interestingly, using bioinformatics, it was found that three other RAGS (VIP, NPY, and GAP-43) had similar sites in their enhancer regions. Finally with respect to galanin expression, there is a high degree of colocalization of c-Jun and galanin expression in DRG neurons after axotomy (Herdegen et al., 1993), and c-Jun has been implicated in galanin induction in axotomized facial motor neurons (Raivich et al., 2004). In sensory neurons, c-Jun induction after axotomy has been attributed in part to the decreased availability of a negative factor, NGF (Gold et al., 1993, 1994) as has the induction of galanin (Shadiack et al., 1998, 2001).

STAT3 phosphorylation occurs after peripheral axotomy in sympathetic, motor, and sensory neurons (Figure 4; Rajan et al., 1995; Haas et al., 1999; Schwaiger et al., 2000; Qiu et al., 2005). In the facial motor nucleus, where no cytokine dependence of neuropeptide gene expression has yet been demonstrated, STAT3 phosphorylation occurs within $12 \mathrm{~h}$ after facial nerve lesion, but this occurrence is delayed a further $12 \mathrm{~h}$ in $\mathrm{CNTF}-/-$ mice, indicating a cytokine influence on the activation of this transcription factor. Interestingly, no activation of STAT3 occurred following transection of axons in two systems in the CNS, namely axons

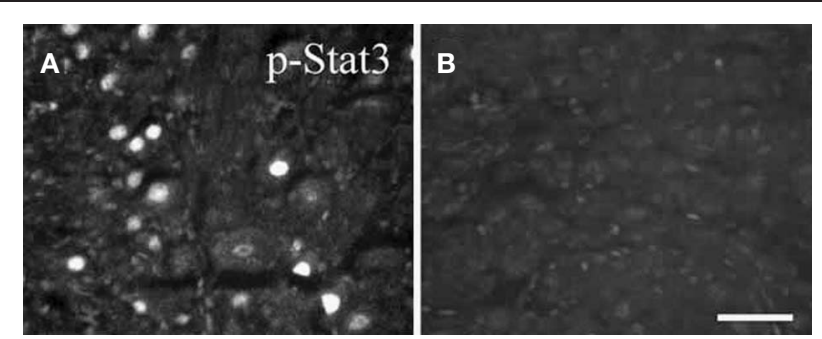

FIGURE 4 | Phospho-STAT3 immunostaining in sections of SCG after axotomy. Forty eight hours after unilateral axotomy, phospho-STAT3 immunostaining was seen in sections of the ipsilateral SCG from wild type (A), but not from gp 130 DBHcre (B), mice. Scale bar $=50 \mu \mathrm{m}$. The figure is from Habecker et al. (2009).

of neurons in Clarke's nucleus and the central processes of DRG neurons in the dorsal columns, neither of which exhibit regeneration (Schwaiger et al., 2000; Qiu et al., 2005). The possible significance of the lack of STAT3 activation in injured CNS neurons is raised toward the end of this review.

While Rajan et al. (1995) reported that axotomy of the SCG in LIF $-/-$ mice produced no activation of STAT3, we found that the increase in STAT3 phosphorylation, though significantly inhibited in those animals, was not abolished (Mohney, 1998). On the other hand, no STAT3 phosphorylation was seen in the SCG after axotomy in gp130 conditional knockout mice (Figure 4; Habecker et al., 2009; Hyatt Sachs et al., 2010), again suggesting the involvement of more than one cytokine in the response to axotomy.

A puzzling aspect about phospho-STAT3 activation after axotomy, at least in the DRG where it has been studied in detail, is its time course. After sciatic nerve transection phospho-STAT3 was maximal in the DRG after $6 \mathrm{~h}$ but was still above control values after a month (Qiu et al., 2005). However, the level of LIF mRNA in the sciatic nerve, though initially elevated had returned to control levels between 7 and 14 days after transection (Curtis et al., 1994). It will be interesting to learn what is responsible for the sustained phosphorylation/activation of this transcription factor.

\section{PARACRINE, AUTOCRINE, AND RETROGRADE MECHANISMS OF gp130 CYTOKINE ACTION ON NEURONS}

Although emphasis has been placed thus far in this review on the synthesis and release of LIF from satellite/Schwann cells within sympathetic ganglia and its paracrine action on the axotomized neurons, LIF can also be synthesized in Schwann cells in axons distal to the injury and retrogradely transported by sensory and motor neurons (Banner and Patterson, 1994; Curtis et al., 1994; Kurek et al., 1996; Sun and Zigmond, 1996b; Thompson et al., 1997). Retrograde transport of LIF (and of CNTF) is actually increased following nerve injury (Curtis et al., 1993, 1994). The transport of radioactive LIF by sensory neurons and spinal motor neurons is specific to LIF and is not inhibited by administration of other cytokines (e.g., CNTF, oncostatin M, and IL-6 with or without the IL-6 soluble receptor; Curtis et al., 1994).

In contrast, following injection of radioactive LIF into the foot pad, no transport of the cytokine to adult lumbar 
sympathetic ganglia was seen (Hendry et al., 1992). This finding is somewhat surprising since neonatal sympathetic neurons in compartmentalized cultures retrogradely transport LIF (Ure and Campenot, 1994). In addition, early studies led to the hypothesis that LIF produced by certain sympathetic target tissues, in particular the sweat gland, could produce a switch in neonatal sympathetic neurons in vivo from an adrenergic to a cholinergic phenotype (Yamamori et al., 1989; Rao and Landis, 1993). However, later studies in which the gp130 cytokines present in the sweat gland were identified and in which the "cholinergic switch" was shown to be normal in LIF -/- mice indicated that LIF is not the gp130 cytokine that is responsible from this retrograde effect (Rao et al., 1993a; Stanke et al., 2006). It remains possible that LIF can be transported by neonatal sympathetic neurons but not adult neurons or by cultured neurons but not neurons in vivo, though the later possibility seems unlikely.

Consistent with the view that some effects of gp130 cytokines involve a retrograde action, STAT3 phosphorylation is seen in cell bodies of sympathetic neurons in compartmentalized cultures after application of LIF to their distal neurites (O'Brien and Nathanson, 2007). Based on this and other data, these workers present a model that LIF bound to its receptor is retrogradely transported to the neuronal cell body in a signaling endosome, analogous to the retrograde mechanism of neurotrophin signaling (Wu et al., 2009). In cell bodies of facial motor neurons, STAT activation following nerve injury can be delayed by three days following treatment with a blocker of axonal transport, colchicine (Kirsch et al., 2003).

In the case of DRG neurons, sciatic nerve transection does not lead to an increase in LIF mRNA within the DRG, though it does in the distal nerve segment (Curtis et al., 1994; Sun and Zigmond, 1996b). Interestingly, DRGs placed in organ culture increased their LIF mRNA dramatically; however, only a slight increase was shown in vivo when both the peripheral and central branches of their axons were cut (Sun and Zigmond, 1996b). However, the increase in galanin was reduced in the axotomized DRG from a LIF - /- mouse compared to a wild type mouse, suggesting an involvement of the retrogradely transported LIF originating in the distal nerve stump (Sun and Zigmond, 1996b). We believe that this is the first demonstration of an often hypothesized phenomenon, namely an effect on an axotomized neuron of a trophic factor or cytokine produced by the distal nerve following injury.

While the neurons in sympathetic ganglia and motor nuclei are generally considered homogenous in terms of trophic factor and cytokine effects, DRG are clearly heterogeneous (e.g., Verge et al., 1995; Marmigere and Ernfors, 2007). In a study on the retrograde transport of biotinylated LIF, the cytokine was found predominantly in small diameter DRG neurons of both the calcitonin gene-related peptide positive $(\mathrm{CGRP}+)$ and the isolectin $\mathrm{B} 4$ positive (IB4+) subtypes (Thompson et al., 1997). Interestingly, these were the predominant neuronal subtype showing cytoplasmic LIF receptor after sciatic nerve transection (Gardiner et al., 2002).

In addition to these paracrine and retrograde mechanisms, it has been suggested that these cytokines can act in an autocrine mechanism. In situ hybridization studies demonstrated IL-6 mRNA in DRG neurons after sciatic nerve transection (Murphy et al., 1995), although an increase in satellite glial cells in these ganglia has also recently been reported (Dubovy et al., 2010). While IL-6 is increased distal to a sciatic nerve lesion (Bolin et al., 1995), in the case of this cytokine, retrograde transport does not seem to occur (Kurek et al., 1996). It would be interesting if this failure of retrograde transport was related to a low level of IL6 receptor protein in DRG neurons. Finally, galanin induction in the axotomized DRG is reduced in the IL-6 -/- mouse, suggesting that the neuronal IL-6 plays an autocrine and (perhaps a paracrine) role in this system. As noted already, such an autocrine action might involve trans-signaling between neurons and satellite cells. While it has also been proposed that in cultured SCG neurons LIF can also play an autocrine role on neuropeptide gene expression (Cheng and Patterson, 1997), the importance of such an action in the SCG compared to LIF's paracrine and retrograde actions is unknown.

\section{THE CONDITIONING LESION RESPONSE IN SENSORY AND SYMPATHETIC NEURONS AND ITS DEPENDENCE ON gp130 CYTOKINES}

In terms of the effects of gp130 cytokines on axonal growth after axotomy, the best studied system is the conditioning lesion response in sensory and sympathetic neurons. This response was first described by McQuarrie and Grafstein as an increase in the rate of growth of silver stained axons in the sciatic nerve following a test lesion if that nerve had been lesioned several days earlier (McQuarrie and Grafstein, 1973). Later studies showed that this conditioning effect occurred in all three fiber types in that nerve, i.e., motor, sensory, and sympathetic (McQuarrie et al., 1977; McQuarrie, 1978; Navarro and Kennedy, 1990).

In addition to an increased rate of regeneration in vivo, it was later found that a conditioning lesion also increased the rate of neurite outgrowth observed subsequently in vitro in explants of DRG or SCG (Edstrom et al., 1996; Shoemaker et al., 2005) or in cultures of dissociated neurons from those ganglia (Hu-Tsai et al., 1994; Shoemaker et al., 2005). Although neurite outgrowths of sensory neurons in vitro are normally inhibited in the presence of the myelin protein, myelin associated glycoprotein (MAG) (Mukhopadhyay et al., 1994), this inhibition is abolished by a conditioning lesion (Qiu et al., 2002). While striking, the functional significance in vivo of inhibition of neurite outgrowth by myelin proteins remains controversial. The axons of transplanted DRG axons have been shown to grow for long distances in CNS white matter, including in areas of degenerating myelin (Davies et al., 1999). Furthermore, experiments with triple knockout mice for MAG and the two other myelin inhibitory proteins that have been examined in detail have produced conflicting results as to the effects of these deletions on CNS regeneration (Cafferty et al., 2010; Lee et al., 2010).

Perhaps the most dramatic effect of a conditioning lesion that has been reported is its effect on growth of sensory neurons into the CNS. When the peripheral branch of a DRG neuron is transected, the axons are capable of regeneration. Normally this is not true when the central branch of these neurons is lesioned (Ramon y Cajal, 1928); however, following a conditioning lesion of the peripheral branches, the lesioned central axons are capable of regenerating both into a peripheral nerve graft (Richardson 
and Issa, 1984) and into the dorsal columns of the spinal cord in the absence of such a graft (Neumann and Woolf, 1999).

The first evidence for the involvement of the JAK/STAT pathway and thereby, perhaps, of gp130 cytokines in the conditioning lesion response was that of Liu and Snider (2001). These investigators looked at the effects of the JAK inhibitor tyrphostin (AG490), which blocks the phosphorylation of STAT3 by JAK2. Administration of this inhibitor in culture blocks the increased outgrowth seen by DRG neurons that have previously received a conditioning lesion (Liu and Snider, 2001). Interestingly, these researchers also reported that inhibitors of the ERK kinase pathway, which as expected blocked NGF stimulated neurite outgrowth from embryonic DRG neurons, had no effect on the conditioning lesion response. Subsequent studies demonstrated that AG490 administered in vivo blocked ingrowth of DRG axons into the dorsal columns (Qiu et al., 2005). In addition, two recent molecular screens on DRGs involving gene microarray analysis, phosphoproteomics or differential hybridization, and bioinformatics have identified STATs generally, or STAT3 specifically, as transcription factors involved in nerve regeneration (Michaelevski et al., 2010; Smith et al., 2011).

It has been well established that analogs of cAMP whether added to a culture of DRG neurons (Cai et al., 1999; Hannila and Filbin, 2008) or injected into the ganglion in vivo (Neumann et al., 2002; Qiu et al., 2002) leads to a conditioning lesion-like growth response. Furthermore, a conditioning lesion leads to an increase in cAMP levels in the DRG (Qiu et al., 2002; Udina et al., 2008). The effect of cAMP on neurite growth on MAG when tested on cerebellar neurons is blocked by an inhibitor of RNA transcription [5,6,-dichlorobenzimidazol ribose (DRB)] (Cai et al., 2002). In contrast, others have reported that the cAMP mediated stimulation of DRG neurite outgrowth on a permissive substrate is not blocked by DRB at a concentration at which RNA synthesis is blocked by $>95 \%$ (Andersen et al., 2000). Interestingly, injections of cAMP into the DRG in vivo lead to an increase of the mRNAs for both IL-6 and LIF and to the phosphorylation and nuclear localization of STAT3 (Wu et al., 2007). Furthermore, the ability of cAMP to stimulate the percentage of DRG neurons with neurites when cultured on a permissive substrate was slightly blocked by AG490 (Wu et al., 2007).

The conditioning lesion effect has been examined also in knockouts of specific gp130 cytokines. The effect of a conditioning lesion on neurite outgrowth of DRG neurons on a permissive substrate was decreased by about $40 \%$ in LIF -/- mice (Cafferty et al., 2001). Interestingly, addition of exogenous LIF into the cultures restored this deficit. In a recent study, it was found that only certain DRG neurons show enhanced neurite outgrowth after a conditioning lesion (Kalous and Keast, 2010). Somewhat surprisingly, those cell types that did not show this effect were the CGRP+ and IB4+ neurons, the very neurons that, as previously noted, showed cytoplasmic localization of LIF receptors and retrograde transport of LIF (Thompson et al., 1997; Gardiner et al., 2002). This issue obviously requires further study.

In IL-6 - - mice, the effect of prior transection of the sciatic nerve on subsequent neurite outgrowth in vitro was reduced by about $65 \%$ (but see below), and addition of exogenous IL-6 to these neurons restored the normal conditioning lesion effect
(Cafferty et al., 2004). These results, together with the experiment of Liu and Snider discussed above using the JAK/STAT inhibitor, indicate that, while these cytokines may play a role immediately following a conditioning lesion, they clearly also play a role in the subsequent response of the conditioned neurons to the test lesion, which in these cases is produced when the ganglia are dissociated and placed in cell culture a week later.

Addition of IL-6 to DRG cultures, like addition of cAMP, blocks the inhibitory effect of MAG on neurite outgrowth and both effects are blocked by DRB, the inhibitor of gene transcription (Cao et al., 2006). Since cAMP leads to an increase in IL-6 mRNA in these neurons, the hypothesis was tested as to whether the ability of cAMP to allow growth on this inhibitory substrate might be mediated through IL-6; however, neither an antibody to gp130, a soluble chimeric form of gp130 fused to Fc, or AG490 blocked the growth response to cAMP (Cao et al., 2006). Furthermore, in contrast to the results of Cafferty discussed above, no differences in neurite outgrowth by DRG neurons after a conditioning lesion were found between wild type and IL-6 -/either in the presence or absence of MAG. These two groups also reported different results on the effect of a conditioning lesion on growth of DRG neurons into the spinal cord after dorsal column lesions, with Cafferty et al. (2004) finding much less growth in IL$6-/-$ compared to wild type animals and Cao et al. (2006) finding no difference between the two strains. In contrast to Cafferty et al., Cao et al. concluded that IL-6 is sufficient, but not necessary, to mediate the conditioning lesion effect. The basis for these different findings is unknown at present.

Thus far, only one downstream mediator of the effects of gp130 cytokine on the conditioning lesion response has been identified, namely galanin (Sachs et al., 2007). Wild type and galanin -/- mice were examined after unilaterally transecting the sciatic nerve. One week later, the ipsilateral and contralateral L4 and L5 DRGs were removed, dissociated, and placed in culture. Neurite outgrowth was greater in neurons isolated from the ipsilateral ganglia in both genotypes; however, the magnitude of the effect was significantly greater in wild type animals (Sachs et al., 2007). Immunohistochemistry established that at the time the ganglia were placed in culture, galanin-IR was substantially increased in small and midsize neurons in the ipsilateral wild type DRGs.

While initially it was believed that sympathetic neurons did not respond to prior injury with increased growth (McQuarrie et al., 1978), it was subsequently found that they did (Figure 5; Navarro and Kennedy, 1990; Shoemaker et al., 2005). When the effect of a conditioning lesion on neurite outgrowth from SCG neurons in culture was examined, no differences were found between wild type and LIF -/- mice either in explant or dissociated cultures (Shoemaker et al., 2005). However, when the same experiments were performed in the gp130 conditional knockouts described above, the stimulation of outgrowth in both preparations was completely abolished (Figure 5; Hyatt Sachs et al., 2010).

These findings on the dependence of the increased neurite outgrowth after a conditioning lesion on gp 130 cytokines is in apparent conflict with a study by $\mathrm{Ng}$ et al. on the inhibitory effects of LIF and CNTF on NGF-directed neurite outgrowth in PC12 cells and neonatal sympathetic neurons (Ng et al., 2003). In that study, 


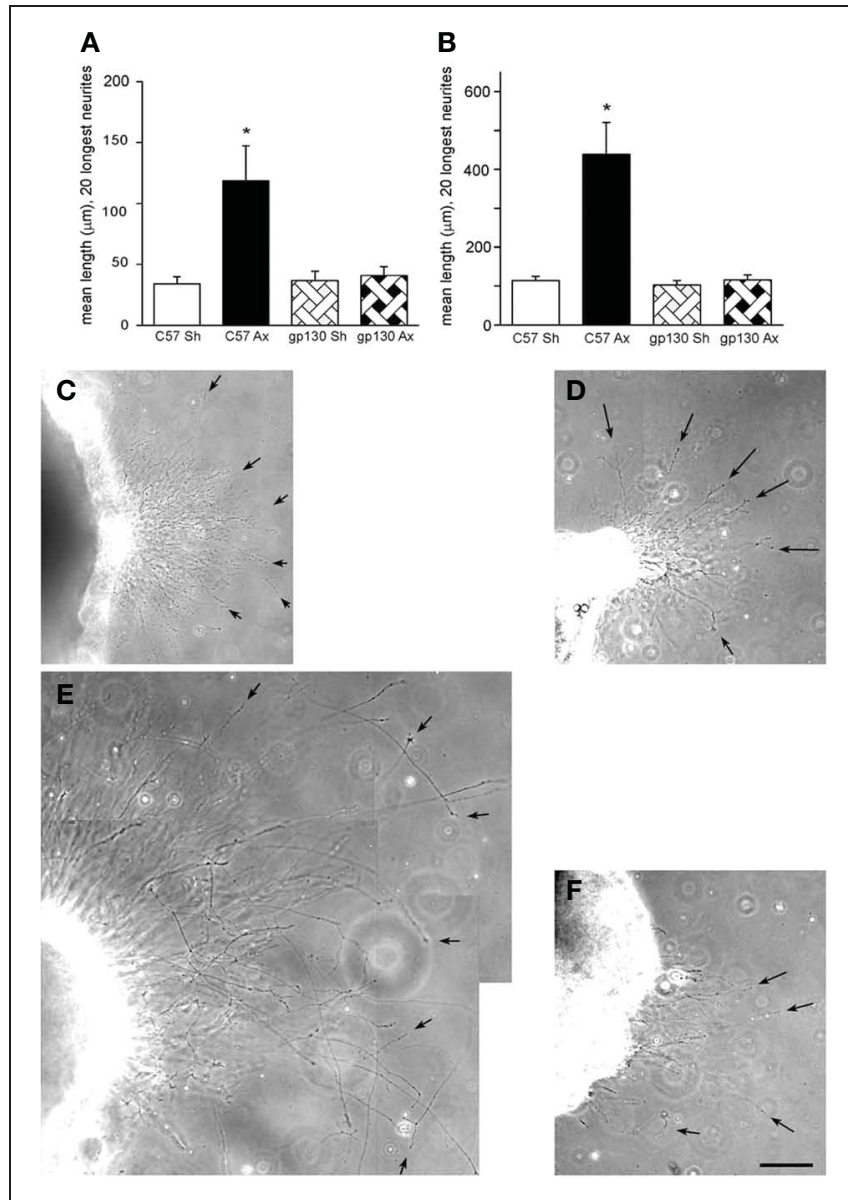

FIGURE 5 | (A, B) Neurite outgrowth was measured from explants of SCGs from wild type (C57) and gp130 DBHcre (gp130) mice following unilateral axotomy. Seven days following surgery, the ipsilateral $(A x)$ and contralateral (Sh) SCGs were placed in Matrigel and maintained in culture. Twenty-four (A) and forty-eight (B) hours later, the explants were photographed under phase contrast microscopy, and the lengths of the 20 longest neurites were determined. The data are presented as means \pm S.E.M. for nine ganglia at $24 \mathrm{~h}$ and for 6-9 ganglia at $48 \mathrm{~h}$. *Represents a difference from the control value of the same genotype at $p<0.003$ by a one-way ANOVA followed by Tukey's post-test. (C-F). Phase contrast micrographs of SCGs placed in explant culture for $48 \mathrm{~h}$. Ganglia from wild type (C, E) and gp130DBHcre (D, F) mice placed in culture seven days after unilateral axotomy. (C) and (D) represent contralateral and (E) and (F) ipsilateral ganglia. Arrows point to individual neurites. The scale bar represents $100 \mu \mathrm{m}$. The figure is from Hyatt Sachs et al. (2010).

NGF cells was found to induce in PC12 cells mRNA for LIF, oncostatin $\mathrm{M}$, and the LIF receptor, none of which were detectable in the absence of NGF. The neurite outgrowth stimulated by NGF in these cells was enhanced if the cells were transfected with a dominant negative form of the LIF receptor, while overexpression of the normal LIF receptor inhibited the outgrowth. Data indicated that cytokines, presumably acting via an autocrine mechanism, decreased Racl activation and increased RhoA activation. In primary sympathetic neurons, CNTF inhibited NGF-stimulated neurite outgrowth on day 1 of treatment though the effect was no longer apparent on day 2. It is hard to reconcile these effects with those of Cafferty et al. on adult DRG neurons. In their studies,
LIF and IL-6 were shown to stimulate an elongated neurite phenotype but only if the cells had been primed with NGF (Cafferty et al., 2001, 2004). Whether these apparent discrepancies are due to differences in the age of the neurons, the cell types examined, or some procedural differences is clearly of interest but remains to be determined.

\section{MIGHT THE gp130 CYTOKINES SYSTEM BE USEFUL FOR FACILITATING REGENERATION IN THE CNS?}

Unlike the peripheral nervous system, little regeneration occurs in the CNS after axonal injury. Four recent developments suggest the possibility that activation of the gp130 cytokine system might facilitate CNS regeneration. Two of these studies involved the response of retinal ganglion cells (RGCs) to a crush of the optic nerve. Normally, there is little regrowth by these damaged axons.

Signaling by gp130 cytokines can be inhibited by a family of proteins called suppressors of cytokine signaling (SOCS), which inhibit JAKs (Wang and Campbell, 2002; Heinrich et al., 2003). To unleash potential gp130 cytokine signaling in a CNS system, a conditional knockout of SOCS3 was produced in the eye. Mutant animals whose SOCS3 gene had been floxed received an intravitreal injection of an adeno-associated virus preparation containing the coding sequence for CRE. The result was an impressive stimulation of RGC axonal outgrowth (Smith et al., 2009). This outgrowth was not seen in animals having both SOCS3 and gp130 knocked out. In situ hybridization indicated an increase in CNTF mRNA in the ganglion cell layer after optic nerve crush, though the cell responsible for this expression was not identified. Injection of CNTF into the eye in the SOCS3 knockout animals further enhanced axonal regeneration.

Some years ago, it was shown that following injury to the lens, RGCs could show impressive axonal outgrowth after an optic nerve crush (Leon et al., 2000). While there has been controversy over the primary mechanism underlying this effect (Muller et al., 2009; Yin et al., 2009), at least one mechanism operating is through gp130 cytokines. Thus, LIF and CNTF double knockout animals do not show the effects of lens injury on neurite outgrowth. In wild type animals, LIF and CNTF mRNA increased in retinal astrocytes after lens injury, and STAT3 phosphorylation increased in RGCs (Leibinger et al., 2009).

Two further examples of the possibility of promoting regeneration in the CNS via these cytokines and the JAK/STAT pathway comes from very recent papers in which neurons were transfected with a constitutively active form of STAT3. In one of these papers, STAT3 was introduced into the DRG by viral gene transfer (Bareyre et al., 2011). Overexpression of STAT3 led to increased STAT3 phosphorylation and to a large increase in terminal sprouting by sensory nerve endings after dorsal column injury. Interestingly, in this same study, a conditional knockout of STAT3 in DRG neurons greatly reduced nerve outgrowth from the saphenous nerve after transection (Bareyre et al., 2011). In the second paper, a constitutively active form of STAT3 was electroporated into cerebellar granular cells, which normally have very low STAT3 expression, and a small (20\%) increase in neurite outgrowth was seen in neurons cultured on a permissive substrate (Smith et al., 2011). 


\section{CONCLUDING THOUGHTS}

gp130 cytokines have long been recognized to be pleiotropic and to have overlapping functions (Taga, 1997). The data discussed in this review suggest that, in both the sympathetic and sensory systems, multiple gp130 cytokines play a role in triggering responses of neurons to injury. A similar situation seems to govern the developmental change in cholinergic properties of sympathetic neurons innervating sweat glands. In that instance, in situ hybridization and laser-capture-microdissection followed by RT-PCR revealed that multiple gp130 cytokines are present in mouse sweat gland coils (Stanke et al., 2006). Although as already noted both exogenous LIF and CNTF trigger a cholinergic switch in these neurons, this switch is not abolished in LIF -/- or CNTF -/- mice or even in double knockout animals (Francis et al., 1997). On the other hand, cholinergic development in these neurons is largely absent in the gp130 conditional knockouts (Stanke et al., 2006), analogous to our findings in adult sympathetic neurons after injury.

As noted, only one downstream mediator of the effects of gp130 cytokine on the conditioning lesion response has been identified, namely galanin, and that only in sensory neurons (Sachs et al., 2007). The fact that the effect on the conditioning lesion response of the null mutation for galanin was only partial suggests that there are other induced proteins involved.

It should be pointed out that all effects of gp130 cytokines on axotomized neurons need not be direct. Both Schwann cells and astrocytes are known to have receptors for these cytokines (Klein et al., 1997; Lee et al., 2009a,b; Wang et al., 2009; Ito et al., 2010; Kirsch et al., 2010), as do macrophages (Hendriks et al., 2008). An interesting example of a quite complicated set of intercellular processes involving LIF concerns this cytokine's ability to stimulate myelination (Ishibashi et al., 2006). In an in vitro

\section{REFERENCES}

Adler, J. E., and Black, I. B. (1984). Plasticity of substance $\mathrm{P}$ in mature and aged sympathetic neurons in culture. Science 225, 1499-1500.

Ambron, R. T., and Walters, E. T. (1996). Priming events and retrograde injury signals. A new perspective on the cellular and molecular biology of nerve regeneration. Mol. Neurobiol. 13, 61-79.

Andersen, P. L., Webber, C. A., Kimura, K. A., and Schreyer, D. J. (2000). Cyclic AMP prevents an increase in GAP-43 but promotes neurite growth in cultured adult rat dorsal root ganglion neurons. Exp. Neurol. 166, 153-165.

Armstrong, B. D., Abad, C., Chhith, S., Cheung-Lau, G., Hajji, O. E., Nobuta, H., and Waschek, J. A. (2008). Impaired nerve regeneration and enhanced neuroinflammatory response in mice lacking pituitary adenylyl cyclase activating peptide. Neuroscience 151, 63-73.
Armstrong, B. D., Hu, Z., Abad, C., Yamamoto, M., Rodriguez, W. I., Cheng, J., Tam, J., Gomariz, R. P., Patterson, P. H., and Waschek, J. A. (2003). Lymphocyte regulation of neuropeptide gene expression after neuronal injury. J. Neurosci. Res. 74, 240-247.

Bacon, A., Kerr, N. C., Holmes, F. E., Gaston, K., and Wynick, D. (2007). Characterization of an enhancer region of the galanin gene that directs expression to the dorsal root ganglion and confers responsiveness to axotomy. J. Neurosci. 27, 6573-6580.

Bando, T., Morikawa, Y., Komori, T., and Senba, E. (2006). Complete overlap of interleukin-31 receptor $\mathrm{A}$ and oncostatin $\mathrm{M}$ receptor beta in the adult dorsal root ganglia with distinct developmental expression patterns. Neuroscience 142, 1263-1271.

Banner, L. R., and Patterson, P. H. (1994). Major changes in the expression of the mRNAs for cholinergic differentiation factor/leukemia

system, electrical stimulation was shown to lead to the neuronal release of ATP, which then acts on astrocytes to release LIF, which finally acts on oligodendrocytes to promote myelination. Whether such a pathway plays a role in the myelination of regenerating axons in vivo is not known. Furthermore, the extent to which similar indirect pathways of cytokine action on regenerating neurons occurs more generally must await future research.

A question long of interest in the regeneration field is to what extent the changes that occur in the adult during regeneration recapitulate changes that occur during initial axonal outgrowth in the embryo and early neonate. The prototypic gene in this regard is GAP-43, which was identified based on the fact that it was present in the embryonic nervous system and not present in the adult except in the peripheral nervous system following nerve injury, where regeneration takes place (Skene and Willard, 1981). With regard to another gene discussed in the current review, galanin has been shown to be expressed in the embryonic DRG starting at embryonic day 14 but not in the adult DRG except after axotomy (Xu et al., 1996). Interestingly, however, deletion of the enhancer region in the galanin gene that completely prevented the axotomy-induced up-regulation of the neuropeptide had no effect on its developmental expression (Bacon et al., 2007). The extent that gp130 cytokines play a role in growth associated genes or in axon elongation during development remains to be determined.

\section{ACKNOWLEDGMENTS}

The research from my laboratory cited in this review was supported by a grant from the National Institutes of Health (NS17512). I would like to thank all those from my laboratory over the years who participated in these studies and particularly Jon Niemi for helpful discussions about the manuscript.

inhibitory factor and its receptor after injury to adult peripheral nerves and ganglia. Proc. Natl. Acad. Sci. U.S.A. 91, 7109-7113.

Bareyre, F. M., Garzorz, N., Lang, C., Misgeld, T., Buning, H., and Kerschensteiner, M. (2011). In vivo imaging reveals a phase-specific role of STAT3 during central and peripheral nervous system axon regeneration. Proc. Natl. Acad. Sci. U.S.A. 108, 6282-6287.

Barrette, B., Calvo, E., Vallieres, N., and Lacroix, S. (2010). Transcriptional profiling of the injured sciatic nerve of mice carrying the Wld(S) mutant gene: identification of genes involved in neuroprotection, neuroinflammation, and nerve regeneration. Brain Behav. Immun. 24, 1254-1267.

Bazan, J. F. (1991). Neuropoietic cytokines in the hematopoietic fold. Neuron 7, 197-208.

Bisby, M. A., and Chen, S. (1990). Delayed wallerian degeneration in sciatic nerves of C57BL/Ola mice is associated with impaired regeneration of sensory axons. Brain Res. 530, 117-120.

Black, I. B., Kessler, J. A., Adler, J. E., and Bohn, M. C. (1982). Regulation of substance $\mathrm{P}$ expression and metabolism in vivo and in vitro. Ciba Found. Symp. 91, 107-122.

Blinzinger, K., and Kreutzberg, G. (1968). Displacement of synaptic terminals from regenerating motoneurons by microglial cells. Z. Zellforsch. Mikrosk. Anat. 85, 145-157.

Boeshore, K. L., Schreiber, R. C., Vaccariello, S. A., Sachs, H. H., Salazar, R., Lee, J., Ratan, R. R., Leahy, P., and Zigmond, R. E. (2004). Novel changes in gene expression following axotomy of a sympathetic ganglion: a microarray analysis. $J$. Neurobiol. 59, 216-235.

Boivin, A., Pineau, I., Barrette, B., Filali, M., Vallieres, N., Rivest, S., and Lacroix, S. (2007). Toll-like receptor signaling is critical for Wallerian degeneration and functional recovery after peripheral 
nerve injury. J. Neurosci. 27, 12565-12576.

Bolin, L. M., Verity, A. N., Silver, J. E., Shooter, E. M., and Abrams, J. S. (1995). Interleukin-6 production by Schwann cells and induction in sciatic nerve injury. J. Neurochem. 64, 850-858.

Bowers, C. W., and Zigmond, R. E. (1979). Localization of neurons in the rat superior cervical ganglion that project into different postganglionic trunks. J. Comp. Neurol. 185, 381-391.

Brandenburg, C. A., May, V., and Braas, K. M. (1997). Identification of endogenous sympathetic neuron pituitary adenylate cyclaseactivating polypeptide (PACAP): depolarization regulates production and secretion through induction of multiple propeptide transcripts. $J$. Neurosci. 17, 4045-4055.

Brazda, V., Klusakova, I., Svizenska, I., Veselkova, Z., and Dubovy, P. (2009). Bilateral changes in IL-6 protein, but not in its receptor gp130, in rat dorsal root ganglia following sciatic nerve ligature. Cell. Mol. Neurobiol. 29, 1053-1062.

Brown, G. L., and Pascoe, J. E. (1954). The effect of degenerative section of ganglionic axons on transmission through the ganglion. J. Physiol. 123, 565-573.

Brown, M. C., Lunn, E. R., and Perry, V. H. (1992). Consequences of slow Wallerian degeneration for regenerating motor and sensory axons. $J$. Neurobiol. 23, 521-536.

Brown, M. C., Perry, V. H., Lunn, E. R., Gordon, S., and Heumann, R. (1991). Macrophage dependence of peripheral sensory nerve regeneration: possible involvement of nerve growth factor. Neuron 6, 359-370.

Burton, M. D., Sparkman, N. L., and Johnson, R. W. (2011). Inhibition of interleukin-6 trans-signaling in the brain facilitates recovery from lipopolysaccharide-induced sickness behavior. J. Neuroinflammation 8, 54 .

Cafferty, W. B., Duffy, P., Huebner, E., and Strittmatter, S. M. (2010). MAG and OMgp synergize with Nogo-A to restrict axonal growth and neurological recovery after spinal cord trauma. J. Neurosci. 30, 6825-6837.

Cafferty, W. B., Gardiner, N. J., Das, P., Qiu, J., McMahon, S. B., and Thompson, S. W. (2004). Conditioning injury-induced spinal axon regeneration fails in interleukin-6 knock-out mice. J. Neurosci. 24, 4432-4443.
Cafferty, W. B., Gardiner, N. J., Gavazzi, I., Powell, J., McMahon, S. B., Heath, J. K., Munson, J., Cohen, J., and Thompson, S. W. (2001). Leukemia inhibitory factor determines the growth status of injured adult sensory neurons. J. Neurosci. 21, 7161-7170.

Cai, D., Deng, K., Mellado, W., Lee, J., Ratan, R. R., and Filbin, M. T. (2002). Arginase I and polyamines act downstream from cyclic AMP in overcoming inhibition of axonal growth MAG and myelin in vitro. Neuron 35, 711-719.

Cai, D., Shen, Y., De Bellard, M., Tang, S., and Filbin, M. T. (1999). Prior exposure to neurotrophins blocks inhibition of axonal regeneration by MAG and myelin via a CAMPdependent mechanism. Neuron 22, 89-101.

Cao, Z., Gao, Y., Bryson, J. B., Hou, J., Chaudhry, N., Siddiq, M., Martinez, J., Spencer, T., Carmel, J., Hart, R. B., and Filbin, M. T. (2006). The cytokine interleukin-6 is sufficient but not necessary to mimic the peripheral conditioning lesion effect on axonal growth. J. Neurosci. 26, 5565-5573.

Cheah, T. B., and Geffen, L. B. (1973). Effects of axonal injury on norepinephrine, tyrosine hydroxylase and monoamine oxidase levels in sympathetic ganglia. J. Neurobiol. 4, 443-452.

Chen, S., and Bisby, M. A. (1993a). Impaired motor axon regeneration in the C57BL/Ola mouse. J. Comp. Neurol. 333, 449-454.

Chen, S., and Bisby, M. A. (1993b). Long-term consequences of impaired regeneration on facial motoneurons in the $\mathrm{C} 57 \mathrm{BL} / \mathrm{Ola}$ mouse. J. Comp. Neurol. 335, 576-585.

Cheng, J. G., and Patterson, P. H. (1997). LIF is an autocrine factor for sympathetic neurons. Mol. Cell. Neurosci. 9, 372-380.

Chung, K., Klein, C. M., and Coggeshall, R. E. (1990). The receptive part of the primary afferent axon is most vulnerable to systemic capsaicin in adult rats. Brain Res. 511, 222-226.

Coleman, M. P., and Freeman, M. R. (2010). Wallerian degeneration, wld(s), and nmnat. Annu. Rev. Neurosci. 33, 245-267.

Cornelissen, C., Luscher-Firzlaff, J., Baron, J. M., and Luscher, B. (2011). Signaling by IL-31 and functional consequences. Eur. J. Cell Biol.

Corness, J., Shi, T. J., Xu, Z. Q., Brulet, P., and Hokfelt, T. (1996). Influence of leukemia inhibitory factor on galanin/GMAP and neuropeptide
$\mathrm{Y}$ expression in mouse primary sensory neurons after axotomy. Exp. Brain Res. 112, 79-88.

Corness, J., Stevens, B., Fields, R. D., and Hokfelt, T. (1998). NGF and LIF both regulate galanin gene expression in primary DRG cultures. Neuroreport 9, 1533-1536.

Costigan, M., Befort, K., Karchewski, L., Griffin, R. S., D'Urso, D., Allchorne, A., Sitarski, J., Mannion, J. W., Pratt, R. E., and Woolf, C. J. (2002). Replicate high-density rat genome oligonucleotide microarrays reveal hundreds of regulated genes in the dorsal root ganglion after peripheral nerve injury. $B M C$ Neurosci. 3, 16

Curtis, R., Adryan, K. M., Zhu, Y., Harkness, P. J., Lindsay, R. M., and DiStefano, P. S. (1993). Retrograde axonal transport of ciliary neurotrophic factor is increased by peripheral nerve injury. Nature 365 , 253-255.

Curtis, R., Scherer, S. S., Somogyi, R., Adryan, K. M., Ip, N. Y., Zhu, Y., Lindsay, R. M., and DiStefano, P. S. (1994). Retrograde axonal transport of LIF is increased by peripheral nerve injury: correlation with increased LIF expression in distal nerve. Neuron 12, 191-204.

Davies, S. J., Goucher, D. R., Doller, C. and Silver, J. (1999). Robust regeneration of adult sensory axons in degenerating white matter of the adult rat spinal cord. J. Neurosci. 19, 5810-5822.

Deckwerth, T. L., and Johnson, E. M. Jr. (1994). Neurites can remain viable after destruction of the neuronal soma by programmed cell death (apoptosis). Dev. Biol. 165, 63-72.

Deutsch, P. J., Schadlow, V. C., and Barzilai, N. (1993). 38-Amino acid form of pituitary adenylate cyclase activating peptide induces process outgrowth in human neuroblastoma cells. J. Neurosci. Res. 35, 312-320.

Diamond, J., Coughlin, M., Macintyre, L., Holmes, M., and Visheau, B. (1987). Evidence that endogenous beta nerve growth factor is responsible for the collateral sprouting, but not the regeneration, of nociceptive axons in adult rats. Proc. Natl. Acad. Sci. U.S.A. 84, 6596-6600.

Diamond, J., Foerster, A., Holmes, M., and Coughlin, M. (1992). Sensory nerves in adult rats regenerate and restore sensory function to the skin independently of endogenous NGF. J. Neurosci. 12, 1467-1476.

DiCicco-Bloom, E., Deutsch, P. J., Maltzman, J., Zhang, J., Pintar, J. E., Zheng, J., Friedman, W. F., Zhou, X., and Zaremba, T. (2000). Autocrine expression and ontogenetic functions of the PACAP ligand/receptor system during sympathetic development. Dev. Biol. 219, 197-213.

Dobrea, G. M., Unnerstall, J. R., and Rao, M. S. (1992). The expression of CNTF message and immunoreactivity in the central and peripheral nervous system of the rat. Brain Res. Dev. Brain Res. 66, 209-219.

Doubleday, B., and Robinson, P. P. (1995). The effect of NGF depletion on the neurotropic influence exerted by the distal stump following nerve transection. J. Anat. 186 (Pt 3), 593-605.

Dubovy, P., Klusakova, I., Svizenska, I., and Brazda, V. (2010). Satellite glial cells express IL-6 and corresponding signal-transducing receptors in the dorsal root ganglia of rat neuropathic pain model. Neuron Glia Biol. 6, 73-83.

Dziennis, S., and Habecker, B. A (2003). Cytokine suppression of dopamine-beta-hydroxylase by extracellular signal-regulated kinase-dependent and -independent pathways. J. Biol. Chem. 278, 15897-15904.

Edstrom, A., Ekstrom, P. A., and Tonge, D. (1996). Axonal outgrowth and neuronal apoptosis in cultured adult mouse dorsal root ganglion preparations: effects of neurotrophins, of inhibition of neurotrophin actions and of prior axotomy. Neuroscience 75, 1165-1174.

Ernsberger, U., Sendtner, M., and Rohrer, H. (1989). Proliferation and differentiation of embryonic chick sympathetic neurons: effects of ciliary neurotrophic factor. Neuron 2, 1275-1284.

Escary, J. L., Perreau, J., Dumenil, D., Ezine, S., and Brulet, P. (1993). Leukaemia inhibitory factor is necessary for maintenance of haematopoietic stem cells and thymocyte stimulation. Nature 363 , 361-364.

Fann, M. J., and Patterson, P. H. (1993). A novel approach to screen for cytokine effects on neuronal gene expression. J. Neurochem. 61, 1349-1355.

Farkas-Szallasi, T., Lundberg, J. M., Wiesenfeld-Hallin, Z., Hokfelt, T. and Szallasi, A. (1995). Increased levels of GMAP, VIP and nitric oxide synthase, and their mRNAs, in lumbar dorsal root ganglia of the rat following systemic resiniferatoxin treatment. Neuroreport 6, 2230-2234.

Fasnacht, N., and Muller, W. (2008). Conditional gp130 deficient mouse mutants. Semin. Cell Dev. Biol. 19, 379-384. 
Fernandes, K. J., Fan, D. P., Tsui, B. J., Cassar, S. L., and Tetzlaff, W. (1999). Influence of the axotomy to cell body distance in rat rubrospinal and spinal motoneurons: differential regulation of GAP-43, tubulins, and neurofilament-M. J. Comp. Neurol. 414, 495-510.

Francis, N. J., Asmus, S. E., and Landis, S. C. (1997). CNTF and LIF are not required for the target-directed acquisition of cholinergic and peptidergic properties by sympathetic neuronsinvivo.Dev. Biol. 182, 76-87.

$\mathrm{Fu}$, S. Y., and Gordon, T. (1997). The cellular and molecular basis of peripheral nerve regeneration. Mol. Neurobiol. 14, 67-116.

Gadient, R. A., and Otten, U. (1996). Postnatal expression of interleukin6 (IL-6) and IL-6 receptor (IL6R) mRNAs in rat sympathetic and sensory ganglia. Brain Res. 724, 41-46.

Gardiner, N. J., Cafferty, W. B., Slack, S. E., and Thompson, S. W. (2002). Expression of gp130 and leukaemia inhibitory factor receptor subunits in adult rat sensory neurones: regulation by nerve injury. J. Neurochem. 83, 100-109.

Gaudet, A. D., Popovich, P. G., and Ramer, M. S. (2011). Wallerian degeneration: gaining perspective on inflammatory events after peripheral nerve injury. $J$. Neuroinflammation $8,110$.

Gloster, A., and Diamond, J. (1992). Sympathetic nerves in adult rats regenerate normally and restore pilomotor function during an anti-NGF treatment that prevents their collateral sprouting. J. Comp. Neurol. 326, 363-374.

Gloster, A., and Diamond, J. (1995). NGF-dependent and NGF-independent recovery of sympathetic function after chemical sympathectomy with 6-hydroxydopamine. J. Comp. Neurol. 359, 586-594.

Gold, B. G., Austin, D. R., and StormDickerson, T. (1994). Multiple signals underlie the axotomy-induced up-regulation of c-JUN in adult sensory neurons. Neurosci. Lett. 176, 123-127.

Gold, B. G., Storm-Dickerson, T., and Austin, D. R. (1993). Regulation of the transcription factor c-JUN by nerve growth factor in adult sensory neurons. Neurosci. Lett. 154, 129-133.

Gordon, T. (2009). The role of neurotrophic factors in nerve regeneration. Neurosurg. Focus 26, E3.

Grafstein, B. (1975). The nerve cell body response to axotomy. Exp. Neurol. 48, 32-51.
Grafstein, B., and McQuarrie, I. G. (1978). "Role of the nerve cell body in axonal regeneration," in Neuronal Plasticity, ed C. W. Cotman (New York: Raven), 155-195.

Greenberg, S. G., and Lasek, R. J. (1988). Neurofilament protein synthesis in DRG neurons decreases more after peripheral axotomy than after central axotomy. J. Neurosci. 8, 1739-1746.

Haas, C. A., Hofmann, H. D., and Kirsch, M. (1999). Expression of CNTF/LIF-receptor components and activation of STAT3 signaling in axotomized facial motoneurons: evidence for a sequential postlesional function of the cytokines. $J$. Neurobiol. 41, 559-571.

Habecker, B. A., Sachs, H. H., Rohrer, H., and Zigmond, R. E. (2009). The dependence on gp130 cytokines of axotomy induced neuropeptide expression in adult sympathetic neurons. Dev. Neurobiol. 69, 392-400.

Hammarberg, H., Piehl, F., Risling, M., and Cullheim, S. (2000). Differential regulation of trophic factor receptor mRNAs in spinal motoneurons after sciatic nerve transection and ventral root avulsion in the rat. J. Comp. Neurol. 426, 587-601.

Hannila, S. S., and Filbin, M. T. (2008). The role of cyclic AMP signaling in promoting axonal regeneration after spinal cord injury. Exp. Neurol. 209, 321-332.

Hanz, S., and Fainzilber, M. (2006). Retrograde signaling in injured nerve - the axon reaction revisited. J. Neurochem. 99, 13-19.

Heinrich, P. C., Behrmann, I., Haan, S., Hermanns, H. M., MullerNewen, G., and Schaper, F. (2003). Principles of interleukin (IL)-6-type cytokine signalling and its regulation. Biochem. J. 374, 1-20.

Heinrich, P. C., Behrmann, I., MullerNewen, G., Schaper, F., and Graeve, L. (1998). Interleukin-6-type cytokine signalling through the gp130/Jak/STAT pathway. Biochem. J. 334 (Pt 2), 297-314.

Hendriks, J. J., Slaets, H., Carmans, S., de Vries, H. E., Dijkstra, C. D., Stinissen, P., and Hellings, N. (2008). Leukemia inhibitory factor modulates production of inflammatory mediators and myelin phagocytosis by macrophages. J. Neuroimmunol. 204, 52-57.

Hendry, I. A. (1992). "Response of autonomic neurones to target deprivation: axotomy and regeneration," in Development, Regeneration and Plasticity of the Autonomic Nervous System, eds I. A. Hendry and
C. E. Hill (Chur: Harwood Academic), 415-462.

Hendry, I. A., Murphy, M., Hilton, D. J., Nicola, N. A., and Bartlett, P. F. (1992). Binding and retrograde transport of leukemia inhibitory factor by the sensory nervous system. J. Neurosci. 12, 3427-3434.

Herdegen, T., Fiallos-Estrada, C. E., Bravo, R., and Zimmermann, M. (1993). Colocalisation and covariation of c-JUN transcription factor with galanin in primary afferent neurons and with CGRP in spinal motoneurons following transection of rat sciatic nerve. Brain Res. Mol. Brain Res. 17, 147-154.

Heumann, R., Korsching, S., Bandtlow, C., and Thoenen, H. (1987). Changes of nerve growth factor synthesis in nonneuronal cells in response to sciatic nerve transection. J. Cell Biol. 104 1623-1631.

Hirota, H., Kiyama, H., Kishimoto, T., and Taga, T. (1996). Accelerated nerve regeneration in mice by upregulated expression of interleukin (IL) 6 and IL-6 receptor after trauma. J. Exp. Med. 183, 2627-2634.

Hokfelt, T., Wiesenfeld-Hallin, Z., Villar, M., and Melander, T. (1987). Increase of galanin-like immunoreactivity in rat dorsal root ganglion cells after peripheral axotomy. Neurosci. Lett. 83, 217-220.

Hokfelt, T., Zhang, X., and WiesenfeldHallin, Z. (1994). Messenger plasticity in primary sensory neurons following axotomy and its functional implications. Trends Neurosci. 17, 22-30.

Holmberg, K., Kuteeva, E., Brumovsky, P., Kahl, U., Karlstrom, H., Lucas, G. A., Rodriguez, J., Westerblad, H., Hilke, S., Theodorsson, E., Berge, O. G., Lendahl, U., Bartfai, T., and Hokfelt, T. (2005). Generation and phenotypic characterization of a galanin overexpressing mouse. Neuroscience 133, 59-77.

Holmes, F. E., Mahoney, S., King, V. R., Bacon, A., Kerr, N. C., Pachnis, V., Curtis, R., Priestley, J. V., and Wynick, D. (2000). Targeted disruption of the galanin gene reduces the number of sensory neurons and their regenerative capacity. Proc. Natl. Acad. Sci. U.S.A. 97, $11563-11568$

Horiuchi, S., Koyanagi, Y., Zhou, Y., Miyamoto, H., Tanaka, Y., Waki, M., Matsumoto, A., Yamamoto, M., and Yamamoto, N. (1994). Soluble interleukin-6 receptors released from $\mathrm{T}$ cell or granulocyte/macrophage cell lines and human peripheral blood mononuclear cells are generated through an alternative splicing mechanism. Eur. J. Immunol. 24, 1945-1948.

Hu-Tsai, M., Winter, J., Emson, P. C., and Woolf, C. J. (1994). Neurite outgrowth and GAP-43 mRNA expression in cultured adult rat dorsal root ganglion neurons: effects of NGF or prior peripheral axotomy. $J$. Neurosci. Res. 39, 634-645.

Hyatt-Sachs, H., Bachoo, M., Schreiber, R., Vaccariello, S. A., and Zigmond, R. E. (1996). Chemical sympathectomy and postganglionic nerve transection produce similar increases in galanin and VIP mRNA but differ in their effects on peptide content. J. Neurobiol. 30, 543-555.

Hyatt-Sachs, H., Schreiber, R. C., Bennett, T. A., and Zigmond, R. E. (1993). Phenotypic plasticity in adult sympathetic ganglia in vivo: effects of deafferentation and axotomy on the expression of vasoactive intestinal peptide. $J$. Neurosci. 13, 1642-1653.

Hyatt Sachs, H., Rohrer, H., and Zigmond, R. E. (2010). The conditioning lesion effect on sympathetic neurite outgrowth is dependent on gp130 cytokines. Exp. Neurol. 223, 516-522.

Ishibashi, T., Dakin, K. A., Stevens, B., Lee, P. R., Kozlov, S. V., Stewart C. L., and Fields, R. D. (2006). Astrocytes promote myelination in response to electrical impulses. Neuron 49, 823-832.

Ito, T., Ikeda, K., Tomita, K., and Yokoyama, S. (2010). Interleukin6 upregulates the expression of PMP22 in cultured rat Schwann cells via a JAK2-dependent pathway. Neurosci. Lett. 472, 104-108.

Johnson, J. A., and Nathanson, N. M. (1994). Differential requirements for p21ras and protein kinase C in the regulation of neuronal gene expression by nerve growth factor and neurokines. J. Biol. Chem. 269, 18856-18863.

Jones, S. A., Horiuchi, S., Topley, N., Yamamoto, N., and Fuller, G. M (2001). The soluble interleukin 6 receptor: mechanisms of production and implications in disease. FASEB J. 15, 43-58.

Jones, S. A., Richards, P. J., Scheller, J., and Rose-John, S. (2005). IL-6 transsignaling: the in vivo consequences. J. Interferon Cytokine Res. 25, 241-253.

Jones, S. A., and Rose-John, S. (2002). The role of soluble receptors in cytokine biology: the agonistic properties of the sIL-6R/IL- 6 complex. Biochim. Biophys. Acta. 1592, 251-263. 
Kalous, A., and Keast, J. R. (2010). Conditioning lesions enhance growth state only in sensory neurons lacking calcitonin gene-related peptide and isolectin B4-binding. Neuroscience 166, 107-121.

Karanth, S., Yang, G., Yeh, J., and Richardson, P. M. (2006). Nature of signals that initiate the immune response during Wallerian degeneration of peripheral nerves. Exp. Neurol. 202, 161-166.

Kashiba, H., Ueda, Y., and Senba, E. (1997). Systemic capsaicin in the adult rat differentially affects gene expression for neuropeptides and neurotrophin receptors in primary sensory neurons. Neuroscience 76, 299-312.

Kato, R., Kiryu-Seo, S., and Kiyama, H. (2002). Damage-induced neuronal endopeptidase (DINE/ECEL) expression is regulated by leukemia inhibitory factor and deprivation of nerve growth factor in rat sensory ganglia after nerve injury. $J$. Neurosci. 22, 9410-9418.

Kessler, J. A., and Black, I. B. (1982). Regulation of substance $\mathrm{P}$ in adult rat sympathetic ganglia. Brain Res. 234, 182-187.

Kirsch, M., Terheggen, U., and Hofmann, H. D. (2003). Ciliary neurotrophic factor is an early lesion-induced retrograde signal for axotomized facial motoneurons. Mol. Cell. Neurosci. 24, 130-138.

Kirsch, M., Trautmann, N., Ernst, M., and Hofmann, H. D. (2010). Involvement of gp130-associated cytokine signaling in Muller cell activation following optic nerve lesion. Glia 58, 768-779.

Kiryu-Seo, S., Kato, R., Ogawa, T., Nakagomi, S., Nagata, K., and Kiyama, H. (2008). Neuronal injury-inducible gene is synergistically regulated by ATF3, c-Jun, and STAT3 through the interaction with Sp1 in damaged neurons. J. Biol. Chem. 283, 6988-6996.

Kiryu-Seo, S., Sasaki, M., Yokohama, H., Nakagomi, S., Hirayama, T., Aoki, S., Wada, K., and Kiyama, H. (2000). Damage-induced neuronal endopeptidase (DINE) is a unique metallopeptidase expressed in response to neuronal damage and activates superoxide scavengers. Proc. Natl. Acad. Sci. U.S.A. 97, 4345-4350.

Klein, M. A., Moller, J. C., Jones, L. L., Bluethmann, H., Kreutzberg, G. W., and Raivich, G. (1997). Impaired neuroglial activation in interleukin6 deficient mice. Glia 19, 227-233.

Klimaschewski, L. (1997). Regulation of galanin in rat sympathetic neurons in vitro. Neurosci. Lett. 234, 87-90.

Klimaschewski, L., Hauser, C. and Heym, C. (1996). PACAP immunoreactivity in the rat superior cervical ganglion in comparison to VIP. Neuroreport 7, 2797-2801.

Klimaschewski, L., Tran, T. D., Nobiling, R., and Heym, C. (1994). Plasticity of postganglionic sympathetic neurons in the rat superior cervical ganglion after axotomy. Microsc. Res. Tech. 29, 120-130.

Klimaschewski, L., Unsicker, K., and Heym, C. (1995). Vasoactive intestinal peptide but not galanin promotes survival of neonatal rat sympathetic neurons and neurite outgrowth of PC12 cells. Neurosci. Lett. 195, 133-136.

Korsching, S., and Thoenen, $\mathrm{H}$. (1985). Treatment with 6hydroxydopamine and colchicine decreases nerve growth factor levels in sympathetic ganglia and increases them in the corresponding target tissues. J. Neurosci. 5, 1058-1061.

Kurek, J. B., Austin, L., Cheema, S. S., Bartlett, P. F., and Murphy, M. (1996). Up-regulation of leukaemia inhibitory factor and interleukin-6 in transected sciatic nerve and muscle following denervation. Neuromuscul. Disord. 6, 105-114.

Lecomte, M. J., Basseville, M., Landon, F., Karpov, V., and Fauquet, M. (1998). Transcriptional activation of the mouse peripherin gene by leukemia inhibitory factor: involvement of STAT proteins. J. Neurochem. 70, 971-982.

Lee, H., Jo, E. K., Choi, S. Y., Oh, S. B., Park, K., Kim, J. S., and Lee, S. J. (2006). Necrotic neuronal cells induce inflammatory Schwann cell activation via TLR2 and TLR3: implication in Wallerian degeneration. Biochem. Biophys. Res. Commun. 350, 742-747.

Lee, H. K., Seo, I. A., Suh, D. J., Hong, J. I., Yoo, Y. H., and Park, H. T. (2009a). Interleukin-6 is required for the early induction of glial fibrillary acidic protein in Schwann cells during Wallerian degeneration. J. Neurochem. 108, 776-786.

Lee, H. K., Wang, L., Shin, Y. K., Lee, K. Y., Suh, D. J., and Park, H. T. (2009b). Interleukin-6 induces proinflammatory signaling in Schwann cells: a high-throughput analysis. Biochem. Biophys. Res. Commun. 382, 410-414.

Lee, J. K., Geoffroy, C. G., Chan, A. F., Tolentino, K. E., Crawford, M. J., Leal, M. A., Kang, B., and Zheng, B. (2010). Assessing spinal axon regeneration and sprouting in Nogo-,
MAG-, and OMgp-deficient mice. Neuron 66, 663-670.

Leibinger, M., Muller, A., Andreadaki, A., Hauk, T. G., Kirsch, M., and Fischer, D. (2009). Neuroprotective and axon growth-promoting effects following inflammatory stimulation on mature retinal ganglion cells in mice depend on ciliary neurotrophic factor and leukemia inhibitory factor. J. Neurosci. 29, 14334-14341

Leinfelder, P. J. (1938). Retrograde degeneration in the optic nerves and retinal ganglion cells. Trans. Am. Ophthalmol. Soc. 36, 307-315

Leon, S., Yin, Y., Nguyen, J., Irwin, N., and Benowitz, L. I. (2000). Lens injury stimulates axon regeneration in the mature rat optic nerve. $J$. Neurosci. 20, 4615-4626.

Lieberman, A. R. (1971). "The axon reaction: a review of the principle features of perikaryal responses to axon injury," in International Review Neurobiology, vol. 14, eds C. C. Pfeiffer and J. R. Smythies (New York, NY: Academic Press), 49-124.

Linker, R. A., Luhder, F., Kallen, K. J. Lee, D. H., Engelhardt, B., RoseJohn, S., and Gold, R. (2008). IL-6 transsignalling modulates the early effector phase of EAE and targets the blood-brain barrier. $J$. Neuroimmunol. 205, 64-72.

Lioudyno, M., Skoglosa, Y., Takei, N., and Lindholm, D. (1998). Pituitary adenylate cyclaseactivating polypeptide (PACAP) protects dorsal root ganglion neurons from death and induces calcitonin gene-related peptide (CGRP) immunoreactivity in vitro J. Neurosci. Res. 51, 243-256.

Liu, R. Y., and Snider, W. D. (2001). Different signaling pathways mediate regenerative versus developmental sensory axon growth. J. Neurosci. 21, RC164.

Livesey, F. J., O’Brien, J. A., Li, M. Smith, A. G., Murphy, L. J., and Hunt, S. P. (1997). A Schwann cell mitogen accompanying regeneration of motor neurons. Nature 390 614-618.

Lu, X., and Richardson, P. M. (1993) Responses of macrophages in rat dorsal root ganglia following peripheral nerve injury. $J$. Neurocytol. 22, 334-341.

Ludlam, W. H., Chandross, K. J., and Kessler, J. A. (1995). LIF-and IL-1 beta-mediated increases in substance $\mathrm{P}$ receptor mRNA in axotomized, explanted or dissociated sympathetic ganglia. Brain Res. 685 , 12-20.

Ludlam, W. H., Zang, Z., McCarson, K. E., Krause, J. E., Spray, D. C., and Kessler, J. A. (1994). mRNAs encoding muscarinic and substance $P$ receptors in cultured sympathetic neurons are differentially regulated by LIF or CNTF. Dev. Biol. 164, 528-539.

Mahoney, S. A., Hosking, R., Farrant, S., Holmes, F. E., Jacoby, A. S., Shine, J., Iismaa, T. P., Scott, M. K., Schmidt, R., and Wynick, D. (2003). The second galanin receptor GalR2 plays a key role in neurite outgrowth from adult sensory neurons. J. Neurosci. 23, 416-421.

Marmigere, F., and Ernfors, P. (2007). Specification and connectivity of neuronal subtypes in the sensory lineage. Nat. Rev. Neurosci. 8, 114-127.

Marz, P., Cheng, J. G., Gadient, R. A., Patterson, P. H., Stoyan, T., Otten, U., and Rose-John, S. (1998). Sympathetic neurons can produce and respond to interleukin 6 . Proc. Natl. Acad. Sci. U.S.A. 95, 3251-3256.

Marz, P., Gadient, R. A., and Otten, U. (1996). Expression of interleukin-6 receptor (IL-6R) and gp130 mRNA in PC12 cells and sympathetic neurons: modulation by tumor necrosis factor alpha (TNF-alpha). Brain Res 706, 71-79.

Marz, P., Herget, T., Lang, E., Otten, U., and Rose-John, S. (1997). Activation of gp130 by IL-6/soluble IL-6 receptor induces neuronal differentiation. Eur. J. Neurosci. 9, 2765-2773.

Marz, P., Otten, U., and Rose-John, S. (1999). Neural activities of IL6-type cytokines often depend on soluble cytokine receptors. Eur. J. Neurosci. 11, 2995-3004.

Matsuoka, I., Nakane, A., and Kurihara, K. (1997). Induction of LIF-mRNA by TGF-beta 1 in Schwann cells. Brain Res. 776, 170-180.

Matthews, M. R., and Nelson, V. H. (1975). Detachment of structurally intact nerve endings from chromatolytic neurones of rat superior cervical ganglion during the depression of synaptic transmission induced by postganglionic axotomy. J. Physiol. 245, 91-135.

Matthews, M. R., and Raisman, G. (1969). The ultrastructure and somatic efferent synapses of small granule-containing cells in the superior cervical ganglion. J. Anat. 105, 255-282.

McQuarrie, I. G. (1978). The effect of a conditioning lesion on the regeneration of motor axons. Brain Res. 152, 597-602.

McQuarrie, I. G., and Grafstein, B. (1973). Axon outgrowth enhanced 
by a previous nerve injury. Arch. Neurol. 29, 53-55.

McQuarrie, I. G., Grafstein, B., Dreyfus, C. F., and Gershon, M. D. (1978). Regeneration of adrenergic axons in rat sciatic nerve: effect of a conditioning lesion. Brain Res. 141, 21-34.

McQuarrie, I. G., Grafstein, B., and Gershon, M. D. (1977). Axonal regeneration in the rat sciatic nerve: effect of a conditioning lesion and of dbcAMP. Brain Res. 132, 443-453.

Melemedjian, O. K., Asiedu, M. N., Tillu, D. V., Peebles, K. A., Yan, J., Ertz, N., Dussor, G. O., and Price, T. J. (2010). IL-6- and NGFinduced rapid control of protein synthesis and nociceptive plasticity via convergent signaling to the eIF4F complex. J. Neurosci. 30, 15113-15123.

Michaelevski, I., Segal-Ruder, Y., Rozenbaum, M., Medzihradszky, K. F., Shalem, O., Coppola, G., Horn-Saban, S., Ben-Yaakov, K., Dagan, S. Y., Rishal, I., Geschwind, D. H., Pilpel, Y., Burlingame, A. L., and Fainzilber, M. (2010). Signaling to transcription networks in the neuronal retrograde injury response. Sci. Signal. 3, ra53.

Mohney, R. P. (1998). Regulation of Peptide Phenotype in Adult Sympathetic Neurons After Axotomy: Evidence for a Role for Vasoactive Intestinal Peptide. Ph.D. thesis, Case Western Reserve University, Cleveland, $\mathrm{OH}$.

Mohney, R. P., Siegel, R. E., and Zigmond, R. E. (1994). Galanin and vasoactive intestinal peptide messenger RNAs increase following axotomy of adult sympathetic neurons. J. Neurobiol. 25, 108-118.

Moller, K., Reimer, M., Ekblad, E., Hannibal, J., Fahrenkrug, J., Kanje, M., and Sundler, F. (1997a). The effects of axotomy and preganglionic denervation on the expression of pituitary adenylate cyclase activating peptide (PACAP), galanin and PACAP type 1 receptors in the rat superior cervical ganglion. Brain Res. 775, 166-182.

Moller, K., Reimer, M., Hannibal, J., Fahrenkrug, J., Sundler, F., and Kanje, M. (1997b). Pituitary adenylate cyclase-activating peptide (PACAP) and PACAP type 1 receptor expression in regenerating adult mouse and rat superior cervical ganglia in vitro. Brain Res. 775, 156-165.

Moore, R. Y. (1989). Cranial motor neurons contain either galanin- or calcitonin gene-related peptidelike immunoreactivity. J. Comp. Neurol. $282,512-522$.
Mukhopadhyay, G., Doherty, P., Walsh, F. S., Crocker, P. R., and Filbin, M. T. (1994). A novel role for myelin-associated glycoprotein as an inhibitor of axonal regeneration. Neuron 13, 757-767.

Muller, A., Hauk, T. G., Leibinger M., Marienfeld, R., and Fischer, D. (2009). Exogenous CNTF stimulates axon regeneration of retinal ganglion cells partially via endogenous CNTF. Mol. Cell. Neurosci. 41, 233-246.

Murphy, P. G., Grondin, J., Altares, M., and Richardson, P. M. (1995). Induction of interleukin-6 in axotomized sensory neurons. J. Neurosci. 15, 5130-5138.

Murphy, P. G., Ramer, M. S., Borthwick, L., Gauldie, J., Richardson, P. M., and Bisby, M. A. (1999). Endogenous interleukin-6 contributes to hypersensitivity to cutaneous stimuli and changes in neuropeptides associated with chronic nerve constriction in mice. Eur. J. Neurosci. 11, 2243-2253.

Nagamoto-Combs, K., Vaccariello, S. A., and Zigmond, R. E. (1999). The levels of leukemia inhibitory factor mRNA in a Schwann cell line are regulated by multiple second messenger pathways. J. Neurochem. 72, 1871-1881.

Nagata, Y., Ando, M., Takahama, K., Iwata, M., Hori, S., and Kato, K. (1987). Retrograde transport of endogenous nerve growth factor in superior cervical ganglion of adult rats. J. Neurochem. 49, 296-302.

Navarro, X., and Kennedy, W. R. (1990). The effect of a conditioning lesion on sudomotor axon regeneration. Brain Res. 509, 232-236.

Nawa, H., Nakanishi, S., and Patterson, P. H. (1991). Recombinant cholinergic differentiation factor (leukemia inhibitory factor) regulates sympathetic neuron phenotype by alterations in the size and amounts of neuropeptide mRNAs. J. Neurochem. 56, 2147-2150.

Neumann, S., Bradke, F., TessierLavigne, M., and Basbaum, A. I. (2002). Regeneration of sensory axons within the injured spinal cord induced by intraganglionic cAMP elevation. Neuron 34, 885-893.

Neumann, S., and Woolf, C. J. (1999). Regeneration of dorsal column fibers into and beyond the lesion site following adult spinal cord injury. Neuron 23, 83-91.

Ng, Y. P., Cheung, Z. H., and Ip, N. Y. (2006). STAT3 as a downstream mediator of Trk signaling and functions. J. Biol. Chem. 281, 15636-15644.
Ng, Y. P., He, W., and Ip, N. Y. (2003). Leukemia inhibitory factor receptor signaling negatively modulates nerve growth factor-induced neurite outgrowth in PC12 cells and sympathetic neurons. J. Biol. Chem. 278, 38731-38739.

Nielsch, U., and Keen, P. (1989). Reciprocal regulation of tachykininand vasoactive intestinal peptidegene expression in rat sensory neurones following cut and crush injury. Brain Res. 481, 25-30.

Nishimune, H., Vasseur, S., Wiese, S., Birling, M. C., Holtmann, B. Sendtner, M., Iovanna, J. L., and Henderson, C. E. (2000). Reg-2 is a motoneuron neurotrophic factor and a signalling intermediate in the CNTF survival pathway. Nat. Cell Biol. 2, 906-914.

Noguchi, K., Senba, E., Morita, Y., Sato, M., and Tohyama, M. (1989). Prepro-VIP and preprotachykinin mRNAs in the rat dorsal root ganglion cells following peripheral axotomy. Brain Res. Mol. Brain Res. 6 , 327-330.

Oblinger, M. M., and Lasek, R. J. (1988). Axotomy-induced alterations in the synthesis and transport of neurofilaments and microtubules in dorsal root ganglion cells. J. Neurosci. 8, 1747-1758.

Oblinger, M. M., Wong, J., and Parysek, L. M. (1989). Axotomy-induced changes in the expression of a type III neuronal intermediate filament gene. J. Neurosci. 9, 3766-3775.

O'Brien, J. J., and Nathanson, N. M. (2007). Retrograde activation of STAT3 by leukemia inhibitory factor in sympathetic neurons. $J$. Neurochem. 103, 288-302.

Okumura, N., Miyatake, Y., Takao, T., Tamaru, T., Nagai, K., Okada, M., and Nakagawa, H. (1994). Vasoactive intestinal peptide induces differentiation and MAP kinase activation in PC12h cells. J. Biochem. 115, 304-308.

Oppenheim, R. W. (1996). The concept of uptake and retrograde transport of neurotrophic molecules during development: history and present status. Neurochem. Res. 21, 769-777.

Perry, V. H., and Brown, M. C. (1992). Macrophages and nerve regeneration. Curr. Opin. Neurobiol. 2, 679-682.

Piehl, F., Arvidsson, U., Johnson, H., Cullheim, S., Dagerlind, A. Ulfhake, B., Cao, Y., Elde, R., Pettersson, R. F., Terenius, L., and Hokfelt, T. (1993). GAP-43, aFGF, CCK and alpha- and beta-CGRP in rat spinal motoneurons subjected to axotomy and/or dorsal root severance. Eur. J. Neurosci. 5, 1321-1333.

Pieraut, S., Laurent-Matha, V., Sar, C., Hubert, T., Mechaly, I., Hilaire, C. Mersel, M., Delpire, E., Valmier, J., and Scamps, F. (2007). NKCC1 phosphorylation stimulates neurite growth of injured adult sensory neurons. J. Neurosci. 27, 6751-6759.

Pieraut, S., Lucas, O., Sangari, S., Sar, C., Boudes, M., Bouffi, C., Noel, D., and Scamps, F. (2011) An autocrine neuronal interleukin6 loop mediates chloride accumulation and $\mathrm{NKCCl}$ phosphorylation in axotomized sensory neurons. J. Neurosci. 31, 13516-13526.

Qiu, J., Cafferty, W. B., McMahon, S. B., and Thompson, S. W. (2005). Conditioning injury-induced spinal axon regeneration requires signal transducer and activator of transcription 3 activation. J. Neurosci. $25,1645-1653$.

Qiu, J., Cai, D., Dai, H., McAtee, M., Hoffman, P. N., Bregman, B. S., and Filbin, M. T. (2002). Spinal axon regeneration induced by elevation of cyclic AMP. Neuron 34, 895-903.

Quesada, M. H., Millar, D. B., and Smejkal, R. (1986). Tubulin synthesis in the regenerating rat superior cervical ganglion: a biphasic response. J. Neurobiol. 17, 77-82.

Raivich, G., Bohatschek, M., Da Costa, C., Iwata, O., Galiano, M., Hristova, M., Nateri, A. S., Makwana, M., Riera-Sans, L., Wolfer, D. P., Lipp, H. P., Aguzzi, A., Wagner, E. F., and Behrens, A. (2004). The AP-1 transcription factor c-Jun is required for efficient axonal regeneration. Neuron 43, 57-67.

Rajan, P., Gearan, T., and Fink, J. S. (1998). Leukemia inhibitory factor and NGF regulate signal transducers and activators of transcription activation in sympathetic ganglia: convergence of cytokine- and neurotrophin-signaling pathways. Brain Res. 802, 198-204.

Rajan, P., Stewart, C. L., and Fink, J. S. (1995). LIF-mediated activation of STAT proteins after neuronal injury in vivo. Neuroreport 6, 2240-2244.

Ramon y Cajal, S. (1928). Degeneration and Regeneration of the Nervous System. New York, NY: Oxford University Press.

Rao, M. S., and Landis, S. C. (1993). Cell interactions that determine sympathetic neuron transmitter phenotype and the neurokines that mediate them. J. Neurobiol. 24, 215-232.

Rao, M. S., Sun, Y., Escary, J. L., Perreau, J., Tresser, S., Patterson, P. H., Zigmond, R. E., Brulet, P., and Landis, S. C. (1993a). Leukemia 
inhibitory factor mediates an injury response but not a target-directed developmental transmitter switch in sympathetic neurons. Neuron 11, 1175-1185.

Rao, M. S., Sun, Y., Vaidyanathan, U., Landis, S. C., and Zigmond, R. E. (1993b). Regulation of substance $\mathrm{P}$ is similar to that of vasoactive intestinal peptide after axotomy or explantation of the rat superior cervical ganglion. J. Neurobiol. 24, 571-580.

Rich, K. M., Yip, H. K., Osborne, P. A., Schmidt, R. E., and Johnson, E. M. Jr. (1984). Role of nerve growth factor in the adult dorsal root ganglia neuron and its response to injury. $J$. Comp. Neurol. 230, 110-118.

Richardson, P. M., and Issa, V. M. (1984). Peripheral injury enhances central regeneration of primary sensory neurones. Nature 309, 791-793.

Rose-John, S. (2003). Interleukin-6 biology is coordinated by membrane bound and soluble receptors. Acta. Biochim. Pol. 50, 603-611.

Saadat, S., Sendtner, M., and Rohrer, H. (1989). Ciliary neurotrophic factor induces cholinergic differentiation of rat sympathetic neurons in culture. J. Cell Biol. 108, 1807-1816.

Sachs, H. H., Wynick, D., and Zigmond, R. E. (2007). Galanin plays a role in the conditioning lesion effect in sensory neurons. Neuroreport 18, 1729-1733.

Saika, T., Senba, E., Noguchi, K., Sato, M., Kubo, T., Matsunaga, T., and Tohyama, M. (1991). Changes in expression of peptides in rat facial motoneurons after facial nerve crushing and resection. Brain Res. Mol. Brain Res. 11, 187-196.

Schreiber, R. C., Hyatt-Sachs, H., Bennett, T. A., and Zigmond, R. E. (1994). Galanin expression increases in adult rat sympathetic neurons after axotomy. Neuroscience 60, 17-27.

Schreiber, R. C., Shadiack, A. M., Bennett, T. A., Sedwick, C. E., and Zigmond, R. E. (1995). Changes in the macrophage population of the rat superior cervical ganglion after postganglionic nerve injury. $J$. Neurobiol. 27, 141-153.

Schwaiger, F. W., Hager, G., Schmitt, A. B., Horvat, A., Streif, R., Spitzer, C., Gamal, S., Breuer, S., Brook, G. A., Nacimiento, W., and Kreutzberg, G. W. (2000). Peripheral but not central axotomy induces changes in Janus kinases (JAK) and signal transducers and activators of transcription (STAT). Eur. J. Neurosci. 12, 1165-1176.
Schweizer, U., Gunnersen, J., Karch, C., Wiese, S., Holtmann, B., Takeda, K., Akira, S., and Sendtner, M. (2002). Conditional gene ablation of Stat 3 reveals differential signaling requirements for survival of motoneurons during development and after nerve injury in the adult. J. Cell Biol. 156, 287-297.

Sendtner, M., Gotz, R., Holtmann, B., Escary, J. L., Masu, Y., Carroll, P., Wolf, E., Brem, G., Brulet, P., and Thoenen, H. (1996). Cryptic physiological trophic support of motoneurons by LIF revealed by double gene targeting of CNTF and LIF. Curr. Biol. 6, 686-694.

Shadiack, A. M., Sun, Y., and Zigmond, R. E. (2001). Nerve growth factor antiserum induces axotomy-like changes in neuropeptide expression in intact sympathetic and sensory neurons. J. Neurosci. 21, 363-371.

Shadiack, A. M., Vaccariello, S. A., Sun, Y., and Zigmond, R. E. (1998). Nerve growth factor inhibits sympathetic neurons' response to an injury cytokine. Proc. Natl. Acad. Sci. U.S.A. 95, 7727-7730.

Shadiack, A. M., Vaccariello, S. A., and Zigmond, R. E. (1995). Galanin expression in sympathetic ganglia after partial axotomy is highly localized to those neurons that are axotomized. Neuroscience 65, 1119-1127.

Shehab, S. A., and Atkinson, M. E. (1986). Vasoactive intestinal polypeptide increases in areas of the dorsal horn of the spinal cord from which other neuropeptides are depleted following peripheral axotomy. Exp. Brain Res. 62, 422-430.

Shi, X., and Habecker, B. A. (2012). gp130 cytokines stimulate proteasomal degradation of tyrosine hydroxylase via extracellular signal regulated kinases 1 and 2. J. Neurochem. 120, 239-247.

Shoemaker, S. E., Sachs, H. H., Vaccariello, S. A., and Zigmond, R. E. (2005). A conditioning lesion enhances sympathetic neurite outgrowth. Exp. Neurol. 194, 432-443.

Shuto, T., Horie, H., Hikawa, N., Sango, K., Tokashiki, A., Murata, H., Yamamoto, I., and Ishikawa, Y. (2001). IL-6 up-regulates CNTF mRNA expression and enhances neurite regeneration. Neuroreport 12, 1081-1085.

Skene, J. H., and Willard, M. (1981). Axonally transported proteins associated with axon growth in rabbit central and peripheral nervous systems. J. Cell Biol. 89, 96-103.
Smith, P. D., Sun, F., Park, K. K., Cai, B., Wang, C., Kuwako, K., MartinezCarrasco, I., Connolly, L., and He, Z. (2009). SOCS3 deletion promotes optic nerve regeneration in vivo. Neuron 64, 617-623.

Smith, R. P., Lerch-Haner, J. K. Pardinas, J. R., Buchser, W. J., Bixby, J. L., and Lemmon, V. P. (2011). Transcriptional profiling of intrinsic PNS factors in the postnatal mouse. Mol. Cell. Neurosci. 46, 32-44.

Sonkoly, E., Muller, A., Lauerma, A. I., Pivarcsi, A., Soto, H., Kemeny, L., Alenius, H., Dieu-Nosjean, M. C., Meller, S., Rieker, J., Steinhoff, M., Hoffmann, T. K., Ruzicka, T., Zlotnik, A., and Homey, B. (2006). IL-31: a new link between $\mathrm{T}$ cells and pruritus in atopic skin inflammation. J. Allergy Clin. Immunol. 117, 411-417.

Stanke, M., Duong, C. V., Pape, M., Geissen, M., Burbach, G., Deller, T., Gascan, H., Otto, C., Parlato, R., Schutz, G., and Rohrer, H. (2006). Target-dependent specification of the neurotransmitter phenotype: cholinergic differentiation of sympathetic neurons is mediated in vivo by gp 130 signaling. Development 133, 141-150.

Sterneck, E., Kaplan, D. R., and Johnson, P. F. (1996). Interleukin-6 induces expression of peripherin and cooperates with Trk receptor signaling to promote neuronal differentiation in $\mathrm{PC1} 2$ cells. J. Neurochem. 67, 1365-1374.

Suarez, V., Guntinas-Lichius, O., Streppel, M., Ingorokva, S., Grosheva, M., Neiss, W. F., Angelov, D. N., and Klimaschewski, L. (2006). The axotomy-induced neuropeptides galanin and pituitary adenylate cyclase-activating peptide promote axonal sprouting of primary afferent and cranial motor neurones. Eur. J. Neurosci. 24, 1555-1564.

Sun, Y., Rao, M. S., Landis, S. C., and Zigmond, R. E. (1992). Depolarization increases vasoactive intestinal peptide- and substance $\mathrm{P}$ like immunoreactivities in cultured neonatal and adult sympathetic neurons. J. Neurosci. 12, 3717-3728.

Sun, Y., Rao, M. S., Zigmond, R. E., and Landis, S. C. (1994). Regulation of vasoactive intestinal peptide expression in sympathetic neurons in culture and after axotomy: the role of cholinergic differentiation factor/leukemia inhibitory factor. $J$. Neurobiol. 25, 415-430.

Sun, Y., Shadiack, A. M., Landis, S. C., and Zigmond, R. E. (1993). Differential effects of cholinergic differentiation factor/leukemia inhibitory factor (CDF/LIF) and NGF on peptide expression in adult rat superior cervical ganglion (SCG). Soc. Neurosci. Abstr. 19, 664.

Sun, Y., and Zigmond, R. E. (1996a). Involvement of leukemia inhibitory factor in the increases in galanin and vasoactive intestinal peptide mRNA and the decreases in neuropeptide $\mathrm{Y}$ and tyrosine hydroxylase mRNA in sympathetic neurons after axotomy. J. Neurochem. 67, 1751-1760.

Sun, Y., and Zigmond, R. E. (1996b). Leukaemia inhibitory factor induced in the sciatic nerve after axotomy is involved in the induction of galanin in sensory neurons. Eur. J. Neurosci. 8, 2213-2220.

Symes, A., Lewis, S., Corpus, L., Rajan, P., Hyman, S. E., and Fink, J. S. (1994). STAT proteins participate in the regulation of the vasoactive intestinal peptide gene by the ciliary neurotrophic factor family of cytokines. Mol. Endocrinol. 8, 1750-1763.

Symes, A. J., Rajan, P., Corpus, L., and Fink, J. S. (1995). C/EBP-related sites in addition to a STAT site are necessary for ciliary neurotrophic factor-leukemia inhibitory factor-dependent transcriptional activation by the vasoactive intestinal peptide cytokine response element. J. Biol. Chem. 270, 8068-8075.

Taga, T. (1997). The signal transducer gp130 is shared by interleukin-6 family of haematopoietic and neurotrophic cytokines. Ann. Med. 29, 63-72.

Taga, T., and Kishimoto, T. (1997). Gp130 and the interleukin-6 family of cytokines. Annu. Rev. Immunol. 15, 797-819.

Taniuchi, M., Clark, H. B., and Johnson, E. M. Jr. (1986). Induction of nerve growth factor receptor in Schwann cells after axotomy. Proc. Natl. Acad. Sci. U.S.A. 83, 4094-4098.

Taniuchi, M., Clark, H. B., Schweitzer, J. B., and Johnson, E. M. Jr. (1988). Expression of nerve growth factor receptors by Schwann cells of axotomized peripheral nerves: ultrastructural location, suppression by axonal contact, and binding properties. J. Neurosci. 8, 664-681.

Tetzlaff, W., Bisby, M. A., and Kreutzberg, G. W. (1988). Changes in cytoskeletal proteins in the rat facial nucleus following axotomy. $J$. Neurosci. 8, 3181-3189.

Thier, M., Marz, P., Otten, U., Weis, J., and Rose-John, S. (1999). Interleukin-6 (IL-6) and its soluble receptor support survival of 
sensory neurons. J. Neurosci. Res. 55, 411-422.

Thompson, S. W., Priestley, J. V., and Southall, A. (1998). gp130 cytokines, leukemia inhibitory factor and interleukin-6, induce neuropeptide expression in intact adult rat sensory neurons in vivo: timecourse, specificity and comparison with sciatic nerve axotomy. Neuroscience 84, 1247-1255.

Thompson, S. W., Vernallis, A. B., Heath, J. K., and Priestley, J. V. (1997). Leukaemia inhibitory factor is retrogradely transported by a distinct population of adult rat sensory neurons: co-localization with trkA and other neurochemical markers. Eur. J. Neurosci. 9, 1244-1251.

Titmus, M. J., and Faber, D. S. (1990). Axotomy-induced alterations in the electrophysiological characteristics of neurons. Prog. Neurobiol. 35, 1-51.

Troy, C. M., Muma, N. A., Greene, L. A., Price, D. L., and Shelanski, M. L. (1990). Regulation of peripherin and neurofilament expression in regenerating rat motor neurons. Brain Res. 529, 232-238.

Udina, E., Furey, M., Busch, S., Silver, J., Gordon, T., and Fouad, K. (2008). Electrical stimulation of intact peripheral sensory axons in rats promotes outgrowth of their central projections. Exp. Neurol. 210, 238-247.

Ure, D. R., and Campenot, R. B. (1994). Leukemia inhibitory factor and nerve growth factor are retrogradely transported and processed by cultured rat sympathetic neurons. Dev. Biol. 162, 339-347.

Vargas, M. E., and Barres, B. A. (2007). Why is Wallerian degeneration in the CNS so slow? Annu. Rev. Neurosci. 30, 153-179.

Verge, V. M., Richardson, P. M. Wiesenfeld-Hallin, Z., and Hokfelt, T. (1995). Differential influence of nerve growth factor on neuropeptide expression in vivo: a novel role in peptide suppression in adult sensory neurons. J. Neurosci. 15, 2081-2096.

Verge, V. M., Wiesenfeld-Hallin, Z., and Hokfelt, T. (1993). Cholecystokinin in mammalian primary sensory neurons and spinal cord: in situ hybridization studies in rat and monkey. Eur. J. Neurosci. 5, 240-250.

Wakisaka, S., Kajander, K. C., and Bennett, G. J. (1991). Increased neuropeptide Y (NPY)-like immunoreactivity in rat sensory neurons following peripheral axotomy. Neurosci. Lett. 124, 200-203.

Wang, J., and Campbell, I. L. (2002). Cytokine signaling in the brain: putting a SOCS in it? J. Neurosci. Res. 67, 423-427.

Wang, L., Lee, H. K., Seo, I. A., Shin, Y. K., Lee, K. Y., and Park, H. T. (2009). Cell type-specific STAT3 activation by gp130-related cytokines in the peripheral nerves. Neuroreport 20, 663-668.

Watanabe, D., Yoshimura, R., Khalil, M., Yoshida, K., Kishimoto, T., Taga, T., and Kiyama, H. (1996). Characteristic localization of gp130 (the signal-transducing receptor component used in common for IL-6/IL-11/CNTF/LIF/OSM) in the rat brain. Eur. J. Neurosci. 8 1630-1640.

Watson, W. E. (1974). Cellular responses to axotomy and to related procedures. $\mathrm{Br}$. Med. Bull. $30,112-115$.

Wong, J., and Oblinger, M. M. (1990). Differential regulation of peripherin and neurofilament gene expression in regenerating rat DRG neurons. J. Neurosci. Res. 27, 332-341.

Wong, V., Pearsall, D., Arriaga, R., Ip, N. Y., Stahl, N., and Lindsay, R. M. (1995). Binding characteristics of ciliary neurotrophic factor to sympathetic neurons and neuronal cell lines. J. Biol. Chem. 270, 313-318.

Wu, C., Cui, B., He, L., Chen, L., and Mobley, W. C. (2009). The coming of age of axonal neurotrophin signaling endosomes. J. Proteomics 72 46-55.

Wu, D., Zhang, Y., Bo, X., Huang, W., Xiao, F., Zhang, X., Miao, T., Magoulas, C., Subang, M. C., and Richardson, P. M. (2007). Actions of neuropoietic cytokines and cyclic AMP in regenerative conditioning of rat primary sensory neurons. Exp. Neurol. 204, 66-76.

$\mathrm{Xu}$, Z. Q., Shi, T. J., and Hokfelt, T. (1996). Expression of galanin and a galanin receptor in several sensory systems and bone anlage of rat embryos. Proc. Natl. Acad. Sci. U.S.A. 93, 14901-14905.

Yamamori, T., Fukada, K., Aebersold, R., Korsching, S., Fann, M. J., and Patterson, P. H. (1989). The cholinergic neuronal differentiation factor from heart cells is identical to leukemia inhibitory factor. Science 246, 1412-1416.

Yin, Y., Cui, Q., Gilbert, H. Y., Yang, Y., Yang, Z., Berlinicke, C., Li, Z., Zaverucha-do-Valle, C., He, H., Petkova, V., Zack, D. J., and Benowitz, L. I. (2009) Oncomodulin links inflammation to optic nerve regeneration. Proc. Natl. Acad. Sci. U.S.A. 106, 19587-19592.

Zhang, Q., Shi, T. J., Ji, R. R., Zhang, Y. Z., Sundler, F., Hannibal, J., Fahrenkrug, J., and Hokfelt, T. (1995). Expression of pituitary adenylate cyclase-activating polypeptide in dorsal root ganglia following axotomy: time course and coexistence. Brain Res. 705, 149-158.

Zhang, X., Dagerlind, A., Bao, L., Ji, R. R., Lundberg, J. M., and Hokfelt, T. (1994). Increased expression of galanin in the rat superior cervical ganglion after pre- and postganglionic nerve lesions. Exp. Neurol. 127, 9-22.

Zhou, X., Rodriguez, W. I., Casillas, R. A., Ma, V., Tam, J., Hu, Z., Lelievre, V., Chao, A., and Waschek, J. A. (1999). Axotomy-induced changes in pituitary adenylate cyclase activating polypeptide (PACAP) and PACAP receptor gene expression in the adult rat facial motor nucleus. $J$. Neurosci. Res. 57, 953-961.

Zhou, X. F., Zettler, C., and Rush, R. A. (1994). An improved procedure for the immunohistochemical localization of nerve growth factorlike immunoreactivity. J. Neurosci. Methods 54, 95-102.

Zigmond, R. E. (1997). LIF, NGF, and the cell body response to axotomy. Neuroscientist 3, 176-185.

Zigmond, R. E. (2001). Can galanin also be considered as growth-associated protein 3.2? Trends Neurosci. 24, 494-496; discussion 496

Zigmond, R. E., Hyatt-Sachs, H. Baldwin, C., Qu, X. M., Sun, Y.,
McKeon, T. W., Schreiber, R. C., and Vaidyanathan, U. (1992). Phenotypic plasticity in adult sympathetic neurons: changes in neuropeptide expression in organ culture. Proc. Natl. Acad. Sci. U.S.A. 89, 1507-1511.

Zigmond, R. E., Hyatt-Sachs, H., Mohney, R. P., Schreiber, R. C. Shadiack, A. M., Sun, Y., and Vaccariello, S. A. (1996). Changes in neuropeptide phenotype after axotomy of adult peripheral neurons and the role of leukemia inhibitory factor. Perspect. Dev. Neurobiol. 4, 75-90.

Zigmond, R. E., and Vaccariello, S. A. (2007). Activating transcription factor 3 immunoreactivity identifies small populations of axotomized neurons in rat cervical sympathetic ganglia after transection of the preganglionic cervical sympathetic trunk. Brain Res. 1159, 119-123.

Zujovic, V., Luo, D., Baker, H. V., Lopez, M. C., Miller, K. R., Streit, W. J., and Harrison, J. K. (2005). The facial motor nucleus transcriptional program in response to peripheral nerve injury identifies $\mathrm{Hn} 1$ as a regeneration-associated gene. J. Neurosci. Res. 82, 581-591.

Conflict of Interest Statement: The authors declare that the research was conducted in the absence of any commercial or financial relationships that could be construed as a potential conflict of interest.

Received: 01 November 2011; accepted: 28 December 2011; published online: 20 January 2012.

Citation: Zigmond RE (2012) gp130 cytokines are positive signals triggering changes in gene expression and axon outgrowth in peripheral neurons following injury. Front. Mol. Neurosci. 4:62. doi: 10.3389/fnmol.2011.00062

Copyright (c) 2012 Zigmond. This is an open-access article distributed under the terms of the Creative Commons Attribution Non Commercial License, which permits non-commercial use, distribution, and reproduction in other forums, provided the original authors and source are credited. 